\title{
A review on the multi-criteria seismic hazard analysis of Ethiopia: with implications of infrastructural development
}

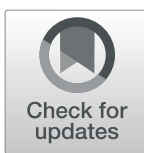

Alemayehu Ayele $^{1 *}$ D, Kifle Woldearegay ${ }^{2}$ and Matebie Meten ${ }^{3}$

\begin{abstract}
Earthquake is a sudden release of energy due to faults. Natural calamities like earthquakes can neither be predicted nor prevented. However, the severity of the damages can be minimized by development of proper infrastructure which includes microzonation studies, appropriate construction procedures and earthquake resistant designs. The earthquake damaging effect depends on the source, path and site conditions. The earthquake ground motion is affected by topography (slope, hill, valley, canyon, ridge and basin effects), groundwater and surface hydrology. The seismic hazard damages are ground shaking, structural damage, retaining structure failures and lifeline hazards. The medium to large earthquake magnitude $(<6)$ reported in Ethiopia are controlled by the main Ethiopian rift System. The spatial and temporal variation of earthquake ground motion should be addressed using the following systematic methodology. The general approaches used to analyze damage of earthquake ground motions are probabilistic seismic hazard assessment (PSHA), deterministic seismic hazard assessment (DSHA) and dynamic site response analysis. PSHA considers all the scenarios of magnitude, distance and site conditions to estimate the intensity of ground motion distribution. Conversely, DSHA taken into account the worst case scenarios or maximum credible earthquake to estimate the intensity of seismic ground motion distribution. Furthermore, to design critical infrastructures, DSHA is more valuable than PSHA. The DSHA and PSHA ground motion distributions are estimated as a function of earthquake magnitude and distance using ground motion prediction equations (GMPEs) at top of the bedrock. Site response analysis performed to estimate the ground motion distributions at ground surface using dynamic properties of the soils such as shear wave velocity, density, modulus reduction, and material damping curves. Seismic hazard evaluation of Ethiopia shown that (i) amplification is occurred in the main Ethiopian Rift due to thick soil, (ii) the probability of earthquake recurrence due to active fault sources. The situation of active fault is oriented in the N-S direction. Ethiopia is involved in huge infrastructural development (including roads, industrial parks and railways), increasing population and agricultural activity in the main Ethiopian Rift system. In this activity, socio-economic development, earthquake and earthquake-generated ground failures need to be given attention in order to reduce losses from seismic hazards and create safe geo-environment.
\end{abstract}

Keywords: Earthquake hazard analysis, DSHA, PSHA, Dynamic response analysis, Ethiopia

\footnotetext{
* Correspondence: alex98geo@gmail.com

'Department of Geology, College of Applied Science, Addis Ababa Science

and Technology University, P.O.Box. 16417, Addis Ababa, Ethiopia

Full list of author information is available at the end of the article
}

\section{Springer Open}

(- The Author(s). 2021 Open Access This article is licensed under a Creative Commons Attribution 4.0 International License, which permits use, sharing, adaptation, distribution and reproduction in any medium or format, as long as you give appropriate credit to the original author(s) and the source, provide a link to the Creative Commons licence, and indicate if changes were made. The images or other third party material in this article are included in the article's Creative Commons licence, unless indicated otherwise in a credit line to the material. If material is not included in the article's Creative Commons licence and your intended use is not permitted by statutory regulation or exceeds the permitted use, you will need to obtain permission directly from the copyright holder. To view a copy of this licence, visit http://creativecommons.org/licenses/by/4.0/. 


\section{Background}

The geo-hazard associated with earthquake is seismic hazards. An earthquake is sudden natural calamities that occur all over the world and confined seismically prone areas (Meissner 2002).

Earthquake related geo-hazard is the probability of a potentially damaging phenomenon occurring within a specified period of time and given area (Varnes 1984); however, the severity of the damages can be minimized by proper infrastructure based on microzonation and seismic design codes (Sitharam and Anbazhagan 2008; Nath and Jakka 2012).

The seismic microzonation studies are the most crucial methods used to mitigate primary and secondary seismic hazard effects such as liquefaction, ground shaking, lateral spreading, structural failure, and landslide, tsunami, flood and fire (Kramer 1996; US Department of Transportation 1997; Nath and Jakka 2012).

The earthquake ground motion at a site is controlled by source, path and site conditions (Kramer 1996). The earthquake ground motion increases with increasing earthquake magnitude and decreasing distance from source; however, the site conditions such as geologic setting, topography, slope and dynamic soil properties show strong variations in earthquake ground shaking intensities than source and path effects (Aki 1998; Borcherdt and Glassmoyer 1970 Boore et al. 1997; Harmsen 1997; Ambrasey and Douglas 2003; Adel et al. 2013; Panjamani et al. 2018). Moreover, to overcome local site amplification effects, seismic microzonation is recommended using integrated geotechnical and geophysical investigation (e.g. Panjamani et al. 2018; Kramer 1996; Panjamani et al. 2018).

The methodologies to be used for seismic hazard microzonations are probabilistic seismic hazard assessment (PSHA) and deterministic hazard assessment (DSHA) (Kramer 1996; TC4- ISSMGE 1999; Anbazhagan et al. 2016). Ethiopia country started building infrastructure on the active Main Ethiopian rift or continental rift margin due to the suitability of land. In addition to that, villages, modern towns and cities are hosting multistory building, industrial park, roads, power plant, recreational site and railway, dams with considerable population density. Nearly all of the major towns in Ethiopia are located either within the rift floor or near the rift margins where earthquake hazard is relatively resulting in high earthquake risk (Ayele 2000; Ayele 2017). Geotechnical studies as reported by Ayalew et al. (2004) revealed that along Main Ethiopian Rift System earth fissuring or cracks were occurred during heavy rain fall and causes property loss. With the on-going infrastructural development, urbanization and rural development, it is foreseeable that the frequency and magnitude of earthquake and losses due to such hazards would continue to increase unless appropriate actions are taken in the Ethiopia. In order to bring the issue of seismic hazard and associated geo-hazards into attention the academia, decision makers and concerned organizations is used this review paper.

\section{Methods of site Characterization}

Site characterization used as an input data to determine seismic hazard assessment and microzonation. This involves acquisition, simulation and interpretation of qualitative and quantitative information about the site of interest. Seismic site characterization can be carried using geological, seismological, geomorphological, hydrogeological, and standard penetration test and multichannel analysis of surface waves (Prasad and Vijayendra 2017; Alemu et al. 2018). The step to be followed for site characterization (Anbazhagan 2013) is given in Fig. 1.

\section{Geological and seismological studies}

Earthquake ground motion depends on magnitude, distance and geology (Kramer 1996). As a result, geological and seismological studies are very important to determine rock type, active fault activity, fault type, fault rupture length, recurrence interval, size of the earthquake, focal depth, epicentral distance and site effect, source identification, rupture area, earthquake catalog and earthquake declustering (e.g. Kramer 1996; Ayele 2000; Boore 2003; Jack and Baker 2008; Ayele 2017). In the Ethiopia, some works were done on the characterization of focal depth mechanism (source parameter) and epicentral distance along the seismic prone area of the Main Ethiopian Rift System (Gouin 1979; Kebede and Van Eck 1996; Midzi et al. 1999; Ayele 2000; Wilks et al. 2017; Ayele 2017; Muluneh et al. 2018), however, data completeness or earthquake catalogue to determine accurate source and path need to be attention on the seismic prone area of Ethiopia. The effect of geology on earthquake ground motion amplification effect is not studied in Ethiopia. So, it is recommendable to assess the damage of infrastructure and loss of property using site specific seismic microzonation.

\section{Remote sensing and GIS- based characterization}

Remote Sensing and Geographic Information System (GIS) designed to characterize seismic site effects based on the interpretation of geomorphology and geology (Alan et al. 2008; Ayele 2017). Furthermore, geotechnical information has extracted from surface information like topographic maps, satellite images, surface geologies, and digital elevation model (DEM), Shuttle Radar Topographic Mission (SRTM) and Advanced Space borne Thermal Emission and Reflection Radiometer (ASTER). Farr and Kobrick (2000) and Wald and Allen (2007) 


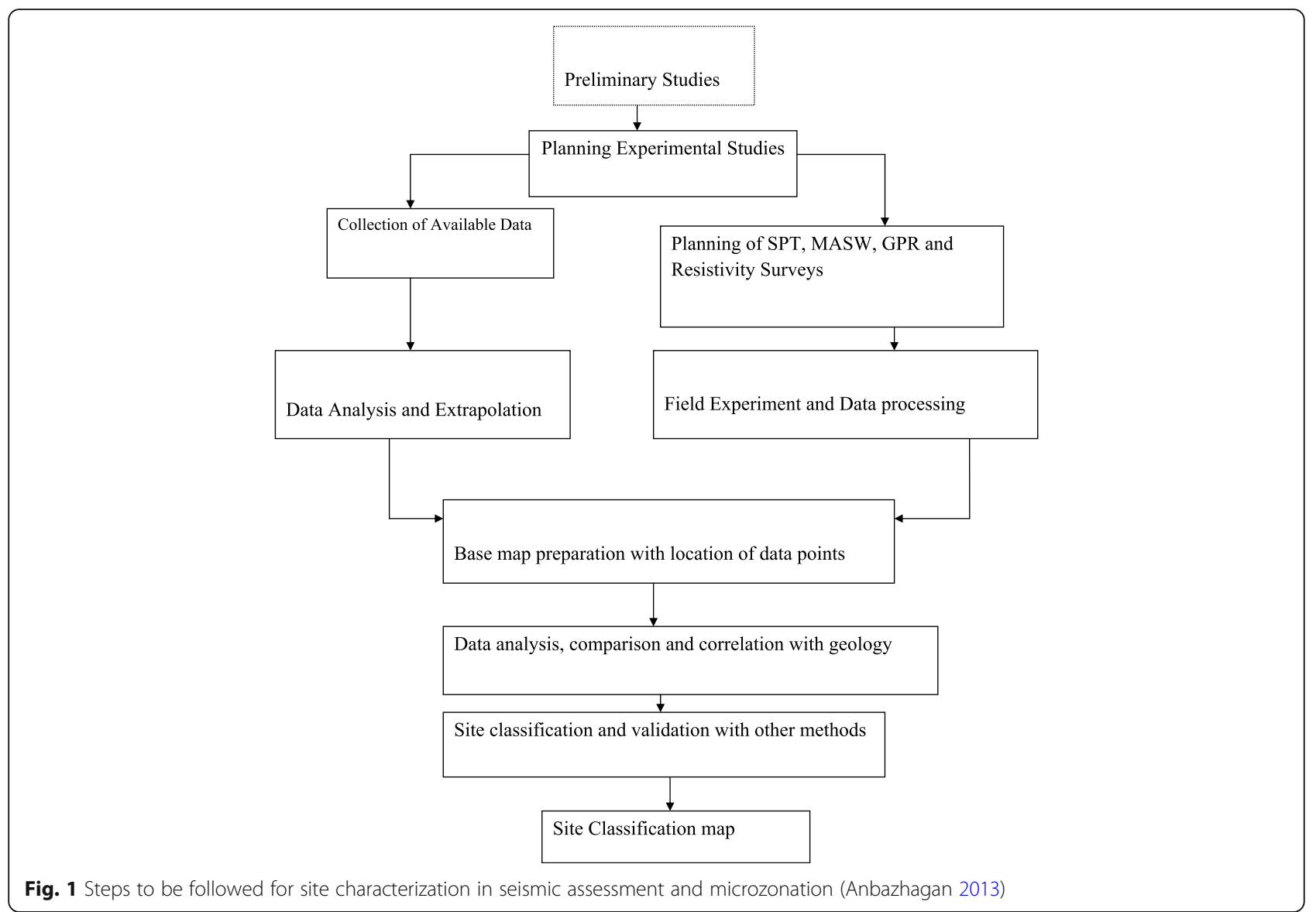

demonstrated that Shuttle Radar Topography Mission (SRTM) model used for mapping seismic site conditions using average shear wave velocity to $30 \mathrm{~m}$ depth. The steep hill slopes are high shear wave velocity than flat basins. So, average shear wave velocity is applicable in regions where transition of steep hill slopes and flat basins (dynamic landscapes). On this regard, mapping of Ethiopia border faults (BF) of the rifts margin, magmatic segments and internal faults of the Wonji fault belt (WFB) along the main Ethiopian Rift system were reported (Simkin et al. 2003; Agostini et al. 2011; Ayele 2017), but the damaging effect of the active Wonji fault belt, earth fissuring, spatial variation of shear wave velocity from rift margin to rift floor relative to the infrastructure is poorly constrained.

\section{Geomorphologic studies}

Iwasaki (1982) and Wakamatsu (1992) revealed that the susceptibility of different geomorphological units are subjected to ground motion: (a) present river bed, old river bed, swamp, reclaimed land and inter-dune low as liquefaction likely, (b) fan, natural levee, sand dune, flood plain, beach and other plains land as liquefaction possibly, and (c) terrace, hill and mountain as liquefaction not likely. History of liquefaction is not documented in the past, nevertheless, due to shallow ground water table, marshy environment, occurrence of lakes, collapsible soil and liquefaction susceptibility soil on the Main Ethiopian Rift System needs to be assessed to reduce socio-economic impact.

\section{Geohydrological response analysis}

Earthquakes change a static stress (i.e., the offset of the fault generates a static change in stress of the crust) into dynamic stresses (from the seismic waves) (Manga and Wang 2015). The static and dynamic stress increase as the seismic moment of the earthquake, but they decay very differently with distance. Loose soil deposit and water table at shallow depth may result in an excessive settlement and liquefaction due to dynamic loading. Also, deep sedimentation widely affects the spectral period and surface amplification (Fritz et al. 2013). The liquefaction effect due to earthquake ground motion near and far epicentral distance in the Ethiopia are not studied. Due to poor evaluation of liquefaction effect in the Ethiopia can cause damage to civil engineering structures. As a result, site characterization should 
incorporate saturated soil interaction with ground motion during seismic site microzonation.

\section{Standard penetration test (SPT)}

SPT is widely used direct in-situ test within a borehole to determine dynamic properties of soil (Anbazhagan et al. 2019). Furthermore, it generally used to investigate cohesionless soil or relatively stiff soil. The variability of the equipment and procedures has significant effects on obtained blow counts (Seed et al. 1985; Skempton 1986). Geotechnical site characterization requires a full 3D representation of stratigraphy, estimation of geotechnical parameters and hydro-geological conditions (Ishihara 2003). Earthquake ground motion can be changed due to stiffness or shear modulus and damping of the soil. Ground failure, site response and liquefaction are strongly influenced by dynamic properties of soil (Kramer 1996).

Soils are highly nonlinear even at very low strains. The nonlinearity causes soil stiffness to decrease and damping to increase with increasing strain amplitude. In this regard, geotechnical site conditions play an important role on damage distribution as well as in the recorded strong motion (Ishihara 1997; Aki 1998; Tertulliani 2000; Hartzell et al. 2001; Özel et al. 2002). A set of correlation between SPT-N values and Vs has proposed on the soil type, depth and geological age (Dikmen 2009; Kuo et al. 2012). The statistical correlations between SPT-N values and Vs for all soils (gravel, sand, silt and clay) are obtained by linear regression (Dikmen 2009). The high correlation coefficient between Vs and SPT-N value shown that SPT-N value has a major effect in Vs estimation. Finally, SPT data used to determine plasticity limit, shear strength, density and cohesion to build engineering structure is applicable for site specific seismic site characterization (Kokusho 1980; Kokusho 1987; Atkinson and Sallfors 1991; Pitilakis et al. 1992; Ishihara 1993; Wazoh and Mallo 2014). Ethiopia, along the Main Ethiopian Rift System, intensive urban development and agricultural activity has been taking place in the past, present and future which is a very worrying process without considering seismic hazard evaluation to save our life.

\section{Multichannel analysis of surface waves (MASW)}

Multichannel analysis of surface waves (MASW) is an indirect geophysical method used to determine shear wave velocity of geomaterials (soil and rock) (Park et al. 1999; Elin et al. 2017). MASW uses active and passive source to generate seismic wave and map weathered and engineering bed rock (Enke et al. 2008; Anbazhagan and Sitharam 2008). It measures surface (Raleigh waves) to generate shear wave velocity profile of dispersion curve by inversion (Park et al. 1999; Elin et al. 2017). In addition to that, average shear wave velocity $\left(\mathrm{Vs}^{30}\right)$ is prepared from shear wave velocity profile to determine the site classes according to Eurocode-8 (2003), NEHRP (BSSC 2015b), International Building Code (IBC 2009), Ministry of Construction 2015 and NEHRP (BSSC 2015a, Dobry et al. 2000; Kanli et al. 2006). Averaged shear-wave velocity up to depth of $30 \mathrm{~m}$ is correlated with site amplification (Aki and Richards 1980; Anbazhagan and Sitharam 2008; Anbazhagan et al. 2010). Finally, the average shear wave velocity $\left(\mathrm{Vs}^{30}\right)$ of soil and rock property used to determine shear modulus $(\mathrm{G})$ of the soil, damping ratio, overburden pressure, void ratio, geologic age, cementation, overconsolidation ratio and strain rate (Hardin and Drnevich 1972; Dobry and Vucetic 1987a, 1987b; Casto et al. 2009; Maheshwari et al. 2013; Mekonen and Kebede 2011; Gashaye 2018). If the average velocity up to $30 \mathrm{~m}$ depth is not well known, it could be calculated by extrapolation based on constant velocity, power law relation and proposed method (Boore 2004; Avouac et al. 2015; Bajaj and Anbazhagan 2019a, 2019b). Statistical analysis revealed that proposed method is more reliable than constant velocity and power law relation (Boore 2004). Seismic waves cross rock-soil interface, propagate through the soil column, the ground motion is generally amplified and its magnitude depends on soil type, soil thickness, soil stiffness, and impedance contrast with the underlying bedrock (Mammo 2005). In this context, the seismic hazard evaluation based on the $\mathrm{Vs}^{30}$ of Ethiopia (Afar depression, escarpment and Main Ethiopian Rift System) is not well done and incorporating as a hazard during geological study.

\section{Standards (adopting codes)}

According to Natural Earthquake Hazard Reduction Provisions (NEHRP) (BSSC 2015b), International Building Code classification (IBC 2009), Dobry et al. 2000; Kanli et al. 2006, Rodriguez-Marek et al. 2001) seismic site characterization for calculating seismic hazard evaluation is carried out based on the average shear wave velocity $\left(\mathrm{Vs}^{30}\right)$ and SPT-N values. The current Ethiopian building seismic code ES EN 1998: 2015 served as a basis for the seismic zoning of Ethiopia with a return period of 100 years corresponds to 0.01 annual probability of exceedance (Kebede and Asfaw 1996; Kebede and Van Eck 1996; Kebede and Van Eck 1997), however, Ethiopian building seismic code (Ministry of Construction 2015) is inadequate, incomplete and non-cognizant due to; i) neglecting local site effects, local fault lines, topography and soil conditions that could amplify earthquake ground motion (Asfaw 1982), ii) considers a return period of 100 years as compared to 475 years return period ( $10 \%$ probability of exceedance in 50 years) and reduces peak ground acceleration by half (Mekonnen 1995) and iii) the catalogue of earthquakes for the current seismic zoning extended up to 1990 and recent 
or new occurred earthquake in the Ethiopia is not included (Asfaw 2003). On this regard, recent expansion on the planning and construction of major building structures as well as infrastructures (including railways, mass housing, dams, bridges, electric transmission line, industrial park) needs to be update of seismic design code in Ethiopia with 475 years return-period.

\section{Site amplification}

The effects of site amplification were observed at some locations during the Mexico (1985) and Loma Prieta (1989) earthquakes due to overlying thick soft soil (Stone et al. 1987; Seed and Harder 1990). The same authors reported that site amplification was directly related with seismic hazard and depends on soil strength, thickness of soil layer and type of soil. The site amplification confirmed, by various scholars (e.g. Borcherdt and Glassmoyer 1970; Cox et al. 2007; Anbazhagan and Sitharam 2008; Anbazhagan et al. 2009; Mukherjee et al. 2014), evaluated empirically using shear wave velocity and SPT-N values. The site amplification due to local soil conditions (alluvium thick soil cover) and topographic effect in the Addis Ababa was highlighted by Asfaw (1982), however, he didn't determine using systematic approach. On this look, Ethiopia metropolitan city which is covered with thick soil and undulating topography need to be studied further for damage reduction of large infrastructures and life.

\section{Factors affecting site amplification}

Along the vicinity, it was noted that source, travel path (distance), magnitude of earthquake and geology (soil and rock), topography, depth to groundwater, basin effect, slope and deep soil affect the degree of strong ground motion (Asfaw 1982; Seed and Schnabel 1972; Seed et al. 1986b; Schnabel et al. 1991; Kramer 1996; Douglas 2001, 2003; Mammo 2005; Bommer et al. 2012). Moreover, estimating their effects can entirely lead to design proper engineering structures (Douglas 2001; Kassegne et al. 2012; Alemu et al. 2018).

\section{Source}

Seismic sources are generally characterized on a faultspecific basis by geometry (location, length, dip angle, depth and distance to the site), seismic potential (earthquake magnitude, activity, recurrence), and style of faulting (strike slip, dip slip, or oblique slip) (Kramer 1996). Source effects are combined effect of earthquake magnitude as well as the characteristics of slip distribution within the fault (Mohamed 2003). The spatial and temporal character of slip fault that rupture due to an earthquake as shown in the Fig. 2 is the central part to predict the ground motion (Brown 2001). Furthermore, the source effect is dependent on input motion, frequency and wave length. At the present in Ethiopia and its neighboring countries, detailed Quaternary fault maps or active faults characteristics like geometry, slip direction and segmentation lengths are not available. In addition to that, accurate hypocentral and epicentral locations (depth and epicentral distance) determinations are insufficient to identify individual seismically active faults (Kebede and Van Eck 1997).

\section{Path}

Path effects can modify as it propagates through earths' crust and strongly control ground motion (Kramer 1996). In addition, the same material during propagation of seismic waves can amplify and attenuate at the same time. This is due to damping ratio and is very high at high frequency than at low frequency (Kramer 1996). Finally, the attenuation of seismic wave amplitude with distance as shown in Fig. 2 is caused by material or viscous damping (absorption) and geometry of wave propagation (radiation damping or scattering) (Kramer 1996).

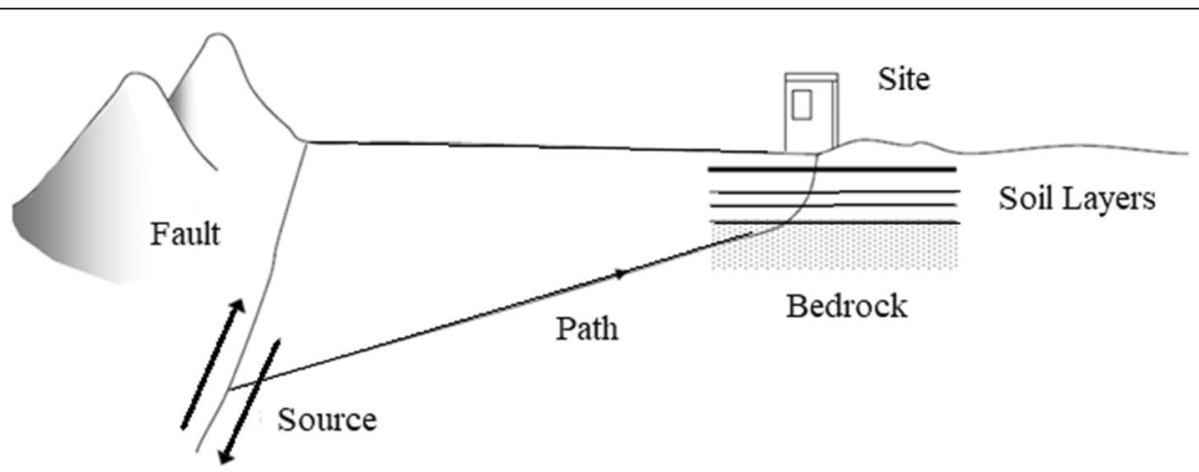

Fig. 2 Ground motion at source, path and Geology (Kramer 1996) 


\section{Site Conditions}

The local geology conditions have profound influence on site response of many earthquakes. Local surface geology and dwelling characteristics are the most commonly claimed factors which influence effects of earthquakes as documented in the recent destructive earthquakes of Michoacan 1985, Loma Prieta, 1989, Kobe 1995 and Izmit, 19991985 Mexico City, 1989 Loma Prieta, 1994 Northridge, and 1995 Kobe earthquakes (Seed et al. 1986a; Chang et al. 1996; Chen et al, 2000). Borcherdt (1970) has demonstrated that both theoretical and empirical methods on near surface geology of site amplification. The geomorphological situations can contribute to the amplification of ground motion that exhibited by topography, basin and edge effects and lithological contacts. Concentration and/ or sharp variations in the severity of damage are commonly attributed to transitions between soft and hard rock lithologies. The numerical models and real case histories have shown strong correlation between damage and surface geology (Midorikawa 1987; Spudich et al. 1997). More specifically, an increase of significant effects has been evidenced near the edge of soft basins (Rovelli 1998). Kramer (1996) produced a model on ground motion propagation from source to site (as shown in Fig. 2). In this regards, some authors in the Ethiopia (e.g Mammo 2005; Worku 2013) tried to consider local site conditions without incorporating topographic effect, but still remain poorly considered. Ethiopia is fast growing country and currently running many mega and mini-projects without considering local site condition to address seismic hazard.

\section{Topography}

Amplification of seismic waves in the presence of topographic irregularities is advocated as one of the possible causes of earthquakes damage as shown in the Fig. 3. As reported in different earthquake cases like the 1985 Canal Beagle Chile earthquake (Celebi 1987; Jafarzadeh et al. 2015), Whittier Narrows 1987 earthquake (Kawase 1990), Aegion Greece 1995 earthquake (Bouckovalas et al. 1999; Bouckovalas and Papadimitriou 2005) and Athens Greece 1999 earthquake (Gazetas et al. 2002) shown that unusually severe earthquake induced damage has been attributed to topographic amplification of earthquake motion. In this case, Ethiopia has contains the Afar Depression, escarpment and Ethiopian Rift System (ERS) seismic source zone (Mammo 2005). On these three seismic source zones, many earthquake activities (magnitude $<7$ ) with associated life lost and damage were reported (Gouin 1979; Asfaw 1990; Wilks et al. 2017; Fardin et al. 2015; Ayele 2017; Midzi et al. 1999), however, they didn't work on how topographic effect amplify or deamplify earthquake ground motion and damage of infrastructure in Ethiopia.

\section{Depth to groundwater}

The presence of water in the subsurface, and changes in the amount of water on the surface or within the subsurface, can influence the occurrence of earthquakes (Manga and Wang 2015). More recent research in the United States has attempted to use monitoring of groundwater levels in wells to predict earthquake activity (Moyle 1980).

Research on earthquake mechanisms indicated that groundwater played a significant and direct role in many large earthquakes (Manga and Wang 2007). The groundwater can magnify damaging effects of ground surface. The effect of earthquake on groundwater can change temperature, geochemistry and pressure and it could be analyzed by monitoring wells before and after earthquake (Manga and Wang 2007).

Ayalew et al. (2004) attempted to show the effect of rain fall on earth fissuring or crack's on the Main rift valley. Ethiopia have many lakes, springs, and rivers, and numerous cities with construction associated with it, but there is no study still on the effect of water to earthquake ground motion (liquefaction) in view of civil engineering structures. As a result, it is need to be work using systematic approach to make our environment safe and sustainable to life. The response of groundwater and surface water to earthquakes is complex and occurs on varying timescales through a number of different mechanisms. The relationship between earth quakes and groundwater processes is presented in Fig. 4.

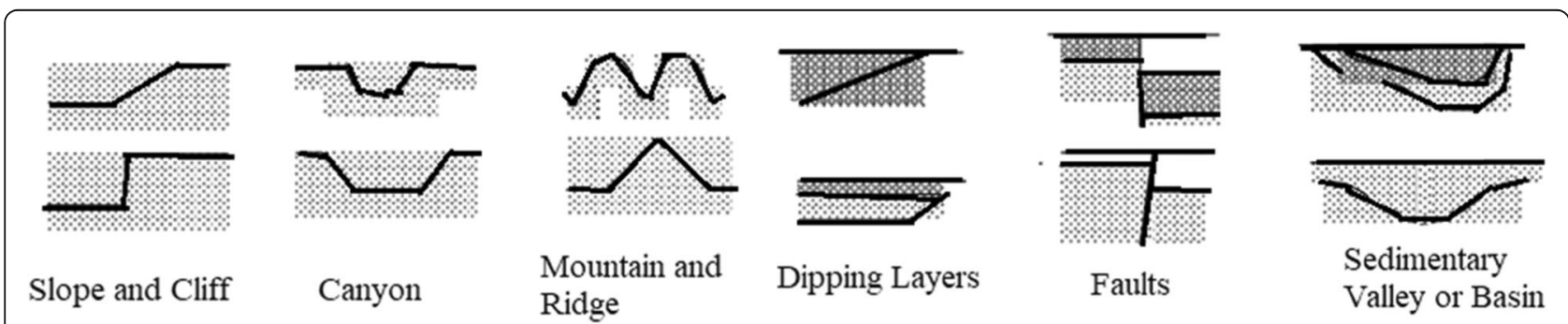

Fig. 3 Idealized examples of surface irregularities and subsurface irregularities (Naganoh et al. 1993) 


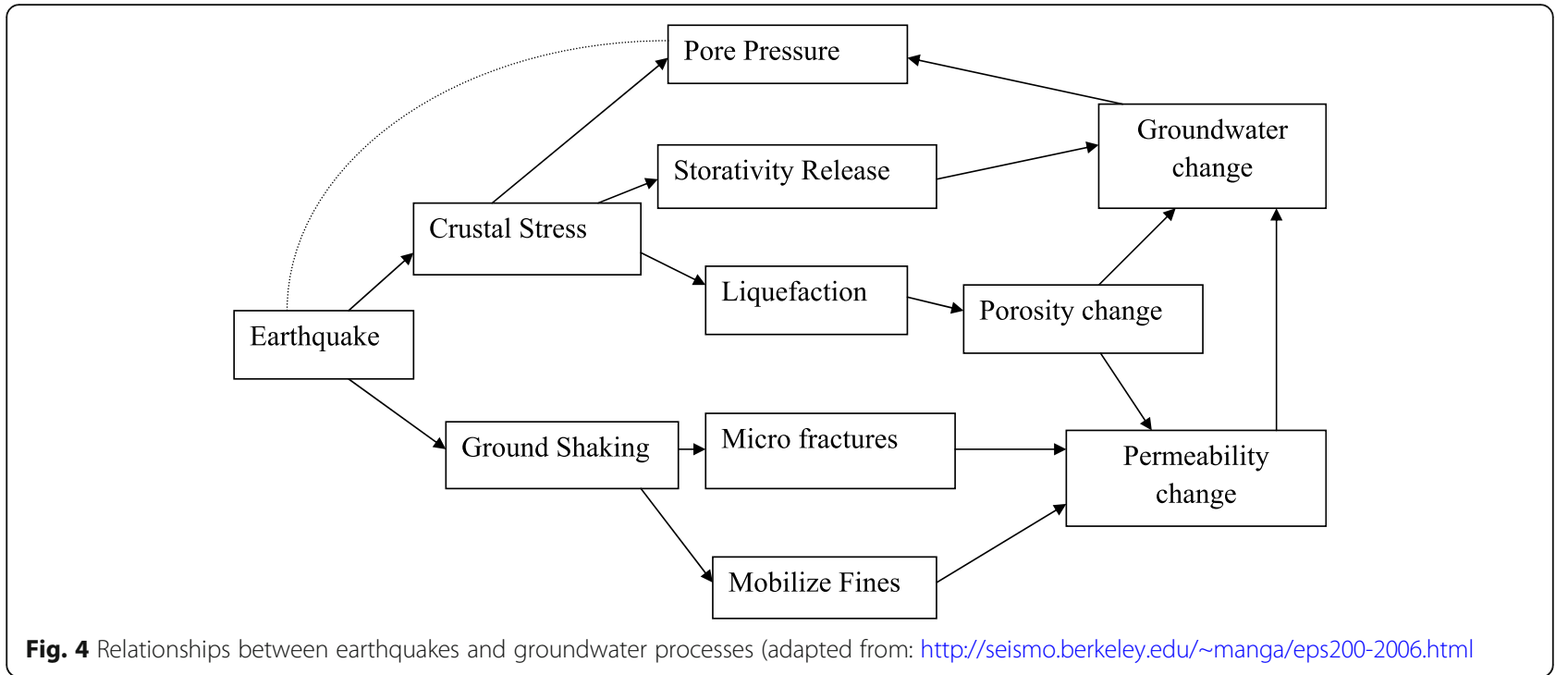

\section{Basin effect}

The presence of softer alluvial soils and curvature of basin will amplify ground motion and increase the duration of motion. King and Tucker (1984) found that the one dimensional ground response analysis can predict the ground response only at the centre of the basin and not at the edges. This variation will have significant effect on the design of long span structures like bridges and pipe lines which are crossing the valley.

Ashford and Sitar (1997) reported that the slope angle of $15 \%-25 \%$ will create the maximum amplification. They find ridges at the top of the hills will amplify the seismic waves and valleys will attenuate the seismic waves. Vittoz et al. (2001) and Graves (1996) have developed a basin effect model in terms of amplification (Fig. 5 and Fig. 6).

\section{Slope}

Fiore (2010) reported that the amplification is a linear function of slope. The same author has been evaluated site amplification values for different slope angles and found that the amplification due to topography will be more at the crest of the slope than bottom of the slope.
Furthermore, Vittoz et al. (2001) concluded that amplification is usually proportional to the ratio of depth (D) over width (W). The relationship of slope and ground motion amplification is shown in the Fig. 7. As Ethiopia, no systematic comparison of slope angle on seismic wave amplification was made for the entire reported seismic hazard (Gouin 1979; Asfaw 1990; Wilks et al. 2017; Ayele 2017; Midzi et al. 1999). All the authors listed here gave some effort on the determination of source parameter (depth of the focus) and epicentral distance using mathematical models, tectonic and geological knowledge. But, Ethiopia has been practiced large population and agricultural activity in the Main Ethiopian rift and Escarpments so that the effect of slope on the ground motion amplification needs to be assessed on the context of economic, social and live aspects.

\section{Deep soil}

The analyses of strong motion records found that the difference of stiffness between the overlying soil and underlying bedrock that affect the amplitude, frequency and duration of seismic waves (Idriss 1990).

Flat Layer Case (1D)
Fig. 5 Propagation of (Critical angle)
Eneismic wave on one layer soil and basin case (Vittoz et al. 2001)
Energy is trapped in top layer




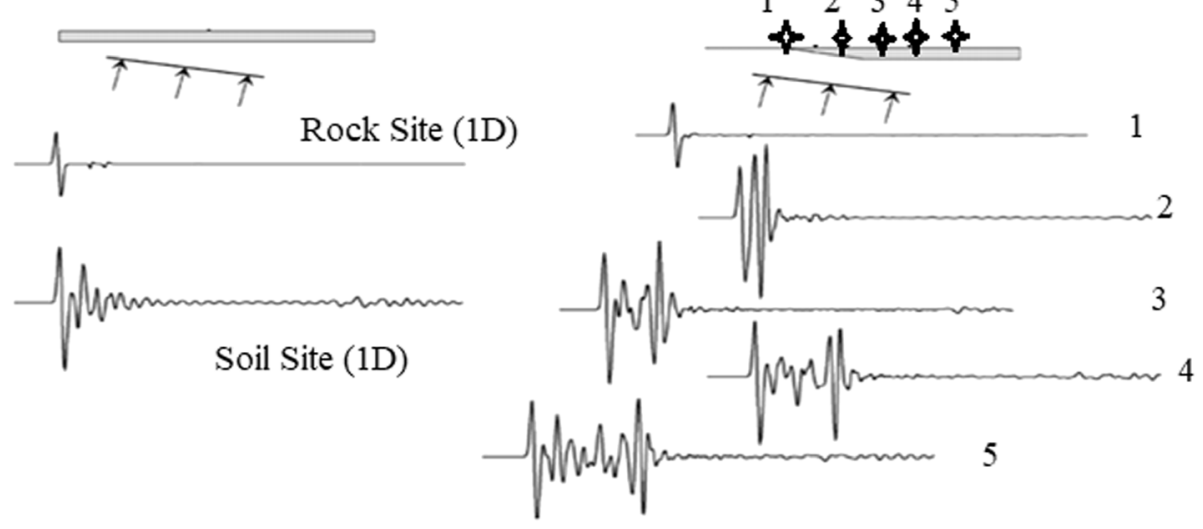

Fig. 6 Effect of basin on ground motion as the wave propagates from \#1 to \#5 (Graves 1996; Vittoz et al. 2001)

These effects were observed during the Mexico (1985) and the Loma Prieta (1989) earthquakes (e.g. Seed et al. 1986b, Chang et al. 1996). The spectral acceleration history at deep soil clearly illustrates that greater effect on seismic wave than rock (Chen and Scawthorn 2003). In Ethiopia context, nearly all deep soil effect on earthquake ground motion is not done by previous researchers (Gouin 1979; Wilks et al. 2017 Ayele 2017).

\section{Seismic Hazard Assessment and Microzonation}

The seismic source, path and local site influence the seismic ground motions need to be characterized to perform seismic hazard analysis (Rahman 2019). Seismic hazard assessment and microzonation consists of (1) Probabilistic Seismic Hazard Analysis (PSHA) or Deterministic Seismic Hazard Analysis (DSHA) followed by Ground Motion Prediction Equation (GMPE); (2) PSHA or/and DSHA followed by dynamic site response analysis; and (3) dynamic site response analysis only (BSSC 2015a). Both deterministic and probabilistic methods performed to complement each other for providing additional insights to seismic hazard and risk problems of decision making purposes (McGuire 2001). Rahman (2019) reported that deterministic and probabilistic ground motion distributions are commonly estimated as

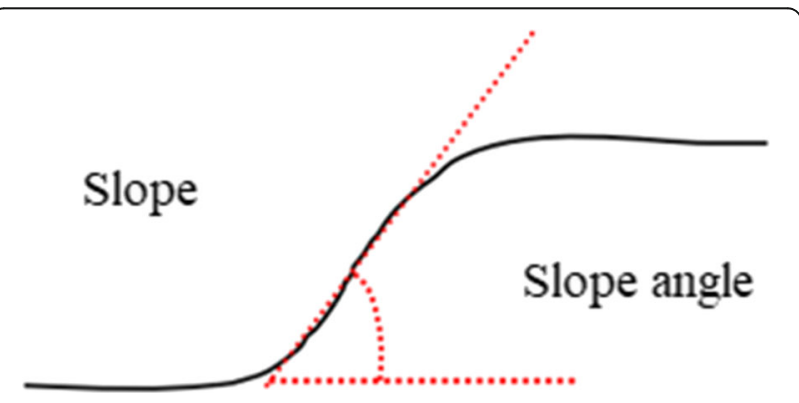

Fig. 7 Effect of slope on ground motion (Vittoz et al. 2001) function of earthquake magnitude and distance, ground motion prediction equations (GMPEs) from the bed rock where time-averaged shear wave velocity in the top $30 \mathrm{~m}$ $\left(\mathrm{Vs}^{30}\right)$ greater or equal to $760 \mathrm{~m} / \mathrm{s}$. The site response analysis is determined using geotechnical investigation like shear wave velocity, density, modulus reduction, and material damping curves, cyclic stress ratio and cyclic resistance ratio (Seed et al. 1986a; Idriss and Sun 1992; Darendeli 2001; Boore 2004; Rahman 2019) as shown in the Fig. 8.

\section{Methods of Seismic Hazard Analysis and Microzonation} Seismic hazard analysis methods at different grade levels are used to assess the effects of earthquake ground motion due to the combined effect of source, distance (path) and local site conditions (Kramer 1996; TC4ISSMGE 1999). The review of the seismic hazard assessment methods includes deterministic seismic hazard analysis, probabilistic seismic hazard analysis (PSHA), and site response analysis and liquefaction potential evaluation (Reiter 1990; Kramer 1996; Midzi et al. 1999; Abrahamson and Silva 2008; Boore and Atkinson 2008; Anbazhagan et al. 2013; Rahman 2019).

\section{Ground Motion Prediction Equation (GMPE)}

The seismic ground motion is measured as a function of magnitude and distance from the source using ground motion prediction equations (GMPEs). The GMPEs are empirically derived from a large number of corrected earthquake ground motion data by statistical regression analysis (Abrahamson and Silva 2008; Boore and Atkinson 2008; Campbell and Bozorgnia 2008; Chiou and Youngs 2008; Idriss and Boulanger 2008).

Kramer (1996) and Bommer et al. (2012) stated that ground motion prediction equations (GMPEs) describe the scaling of ground motion amplitudes with magnitude, style-of-faulting and site class, and decay (attenuation) of the amplitudes at any distances from source. 


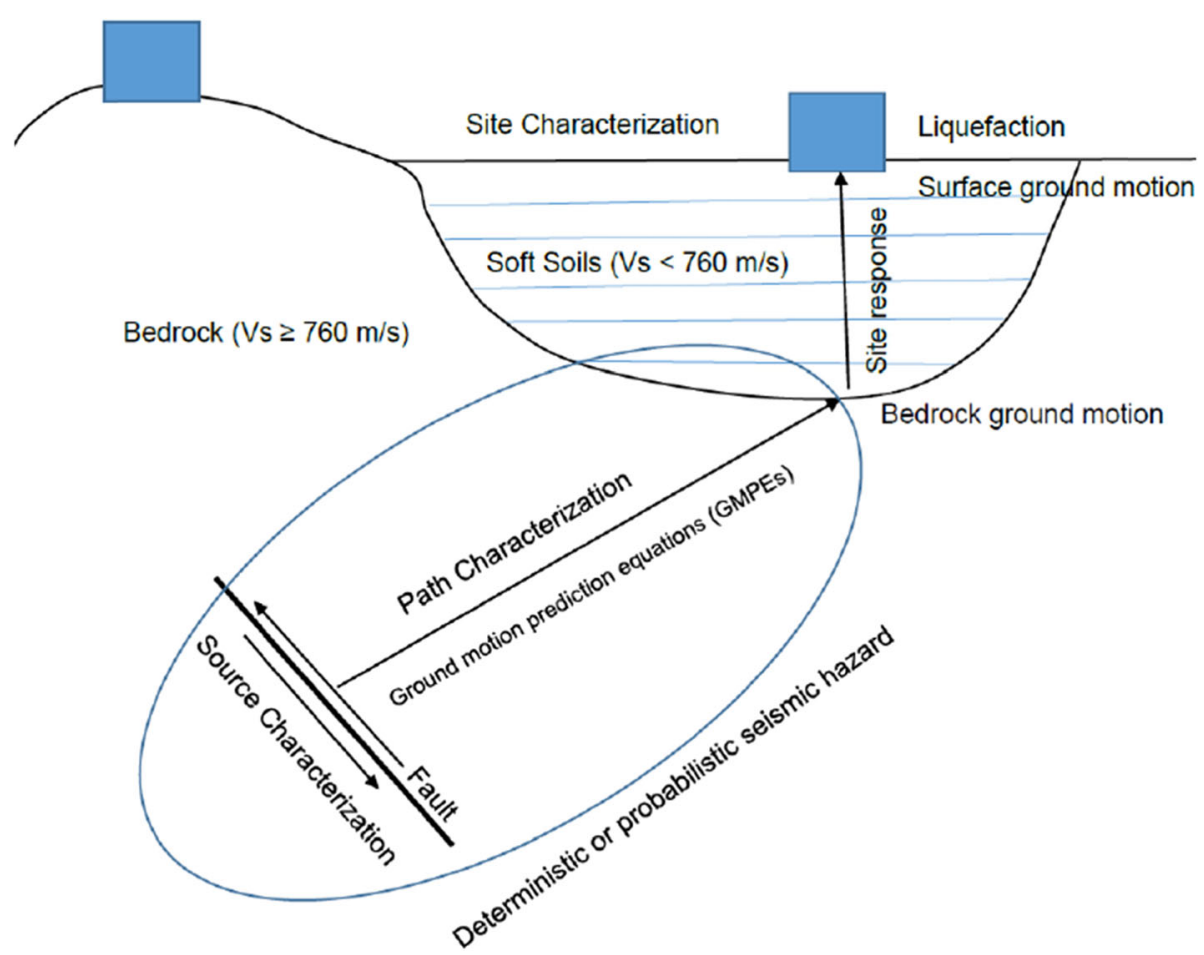

Fig. 8 Conceptual Components of seismic hazard analysis (Rahman 2019)

To develop the GMPE for any region, it needs instrumented ground motion data base, but unfortunately available recorded earthquakes are very limited for such studies (Kramer 1996). However, statistical models of ground motion prediction equation have been used for limited instrumentally recorded earthquake data base region. As a result, due to unavailability of strong ground motion data, there is no developed ground motion prediction equation in Ethiopia. So, many authors (e.g Kebede and Asfaw 1996; Asfaw 2003; Wilks et al. 2017; Ayele 2017; Gashaye 2018) adopted ground motion prediction equations from the Next Generation Attenuation (NGA) and PEER data base for seismic hazard assessment study in Ethiopia. The reason why they were adopting the ground motion prediction or attenuation equation to Ethiopia from the Western USA are (i) both California and Ethiopia has shallow depth of earthquake (ii) the plate boundary in both regions are divergent (Kebede and Asfaw 1996; Asfaw 2003; Haile 2004; Wilks et al. 2017; Ayele 2017; Gashaye 2018).

\section{Deterministic Seismic Hazard Assessment (DSHA)}

Deterministic seismic hazard analysis (DSHA) is the dominant method in earthquake engineering and considers worst scenario earthquake magnitude for engineering design (Reiter 1990; Kramer 1996). Furthermore, the scenario is based on the maximum credible earthquake (MCE) that occur earthquake of a specific size (magnitude) at specific location (Kramer 1996). It is strongly recommended that the deterministic method used for critical engineering projects where consequences of failure are intolerable (Krinitzsky 1995).

The four steps to be followed in deterministic seismic hazard method are (Reiter 1990; Kramer 1996; Krinitzsky 2003 Baker 2008):

i. All earthquake sources producing significant ground motion are identified and characterized, then the geometry and earthquake potential of each source are defined.

ii. The source-to-site distance is measured for each source. In most DSHA, the shortest distance between the source zone and a site of interest is determined. The epicentral or hypocentral distance is used depending on measuring distance of the ground motion prediction equations (GMPEs).

iii. The controlling earthquake expected to generate the strongest shaking at a site is determined. The shaking is generally expressed at the site in terms of some ground motion parameters. The controlling earthquake is defined in terms of its size (magnitude) and distance from a site.

iv. The seismic hazard is expressed in terms of ground motions generated at a site by controlling 
earthquake. The characteristics of the controlling earthquake are generally defined by one or more ground motion parameters that are estimated using ground motion prediction equations (GMPEs). Peak ground acceleration, peak ground velocity, and spectral response spectrum are frequently used to estimate seismic hazard at a site.

In this regard, many researchers in our country (e.g Gouin 1979; Kebede and Van Eck 1997; Asfaw 1998; Hofstetter and Beyth 2003; Fantahun 2016; Wilks et al. 2017; Ayele 2017) with earthquake magnitude $<6$ reported and causes a rock slide, building collapse and loss of life; however, these all researchers used probabilistic approach to map seismic hazard. On contrary, some researchers (e.g Haile 2004; Mengistu 2003; Mammo 2005; Gashaye 2018) tried to determine the local site effect using deterministic approach; however, they did at selected site by neglecting the effect of topography and slope. The probabilistic approach is not good to map seismic hazard at local scale (Rahman 2019). As a result, many critical infrastructures like dams, high ways, roads, railway, power plant, industrial park, electric transmission lines and agricultural activity, building structures need to be addressed by site-specific seismic code before starting any type of construction. Finally, the current seismic hazard zonation is developed in Ethiopia using probabilistic approach and a regional at scale so that it can't represent local soil conditions. To include the response of local site condition, it is recommended that deterministic approach is a good way to analyze local site effects.

\section{Probabilistic seismic Hazard assessment (PSHA)}

In the PSHA method, all possible earthquake sources, average activity rates, magnitudes and distances are considered to estimate intensity of ground motion (Cornell 1968; Kramer 1996; Esteva 1969). The annual rate of exceedance of ground motion is expressed in terms of peak ground acceleration, peak ground velocity or spectral acceleration at a site and its output is seismic hazard curve (McGuire 2008). The probabilistic seismic hazard assessment (PSHA) take in to account the uncertainties associated with size, location, rate of occurrence of earthquakes, and the variations of ground motion characteristics (Kramer 1996).

The PSHA can be described based on the five steps (Cornell 1968; Kramer 1996; Baker 2008, 2013).

i. All sources capable of producing damaging earthquakes are identified.

ii. The distribution of earthquake magnitudes (the expected rate of occurrence of various magnitudes) is predicted. iii. The distribution of the source-to-site distances of potential earthquakes is estimated.

iv. The distribution of ground motion as a function of earthquake magnitude and distance using appropriate ground motion prediction equations (GMPEs) is predicted.

v. The uncertainties in earthquake size, location and ground motion parameters are combined to predict ground motion that will be exceeded during a specific time period using a calculation known as total probability theorem.

As reviewed of seismic hazard assessment and microzonation in Ethiopia, Gouin (1976) produced first seismic hazard map based on the probabilistic method which helped as the basis for developing first Ethiopia building code, ESCP-1:1983, however, his seismic hazard map was developed by considering a large number of destructive earthquakes occurred in the country causing damage to social, economic and human life. Furthermore, Kebede and Asfaw (1996) revised the map and results were used as an input to the second building code of the country (EBCS-8:199). Kebede and Van Eck (1997) revisited the seismic hazard analysis for Ethiopia and neighboring countries with no much difference from Kebede (1996) in approach and results, nonetheless considered spectral response analysis for some economic cities and towns. In addition to that, Midzi et al. (1999) studied the seismic hazard map of Ethiopia and neighboring countries by considering site effect of rock at regional scale of $10 \%$ exceedance for 50 years. Finally, the probabilistic seismic hazard analysis in Ethiopia and neighboring countries that included Poisson earthquake source model and proper catalogue declustering reported by Ayele (2017) for 475 return periods used to produce the 3rd generation building code of the Ethiopia. All the conducted studies in Ethiopia so far are lack of local site effect or ground response analysis, topographic effect, groundwater response and slope. As a result, the seismic hazard map of Ethiopia to be accurate for seismic design of any engineering structures of economical cities need the detail analysis on dynamic properties of soil or local soil conditions, topographic and slope effects, groundwater hydrology, active faults, slip rate and fault length. Finally, further multidisciplinary investigations (e.g., logic tree considerations) are required to improve the map of Ethiopia.

\section{Seismic site response analysis}

The seismic wave alters as it propagates from rock to soil stratum (Akhila et al. 2012). As reported by various authors (Kramer 1996; Hashash et al. 2010; Kaklamanos et al. 2013) the parameters need to be determined in ground site response analysis of ground motion are 
earthquake magnitude, local geology, surface topography, fault mechanism, path between source and site, and dynamic properties of the soil. Evidence from past global earthquake events (e.g Phillips and Aki 1986; Wills and Clahan 2006; Semblat et al. 2000; Slob et al. 2002; Stewart et al. 2003; Topal et al. 2003; Pitilakis et al. 2004) shown that amplification of ground motion is extremely dependent on local geology, topography and geotechnical conditions. Various numerical methods for 1D site response analysis including time-domain nonlinear (NL) method (e.g., Kramer 1996; Kramer and Paulsen 2004; Adel and Cortez-Flores 2004), cyclic wise equivalent linear method (Kramer 1996) and frequencydomain equivalent-linear (EQL) method (Schnabel et al. 1972a, 1972b, 1972c; Kramer 1996) have been compared based on the merits and demerits of analysis. The flow chart for ground response analysis (Anbazhagan 2013; Soebowo 2016) is shown in Fig. 9.

In this regard, some efforts in Ethiopia tried to address ground response analysis on certain economic cities and towns. For instance, Haile (2004) determined period and Fourier amplitude for the city of Addis Ababa using microtremors. Mammo (2005) site-specific ground motion simulation and seismic response analysis using stochastic modeling and some master students of AAU (Mengistu 2003; Gashaye 2018) on seismic response analysis and micozonation at selected site of Addis Ababa were done. All researches worked site response analysis in Addis Ababa city is not include average shear wave velocity $\left(\mathrm{Vs}^{30}\right)$ map, natural frequency, shear modulus map, groundwater effect, topographic and slope on ground motion and needs to be attention for future work in engineering design. In addition, Mekonen and Kebede (2011) demonstrated that soil amplification studies on seismic hazard assessment of some selected parts of Adama town. Finally, Alemu et al. (2018) ground response analysis of representative sites of Hawassa City was reported using empirical method. According to this authors, nothing considered on the detail site response analysis, liquefaction effect, shear modulus, average shear wave velocity $\left(\mathrm{Vs}^{30}\right)$ map, natural frequency, and topographic and slope effect since as it coincide epicenter of destructive earthquake magnitude on thick soil stratum of Main Ethiopian Rift System.

\section{Methods to estimate site response analysis}

The relationship between stress-strain and shear strength (Kramer 1996; Papathanassiou et al. 2005; Matthew et al. 2017; Ishihara 2003) is used to evaluate behavior of soils under cyclic loads. Dynamic shear modulus (G/Gmax), damping ratio and their variation with shear strain is regarded as the dynamic stress-strain properties of soils and used for site response analyses (Ishihara 1982; Seed et al. 1986a; Dobry and Vucetic 1987b; Sun et al. 1988; Bolt, 1999). During earthquakes, soils are subjected to irregular dynamic loads that cause stiffness degradation and shear strength with respect to number of cycles. As a result, the behavior of soils subjected to cyclic loading has been studied by various researchers (Seed and Idriss 1970; Castro and Christian 1976).

Shear modulus and shear wave velocity are primarily functions of soil density, void ratio, and effective stress, with secondary influences including soil type, age,

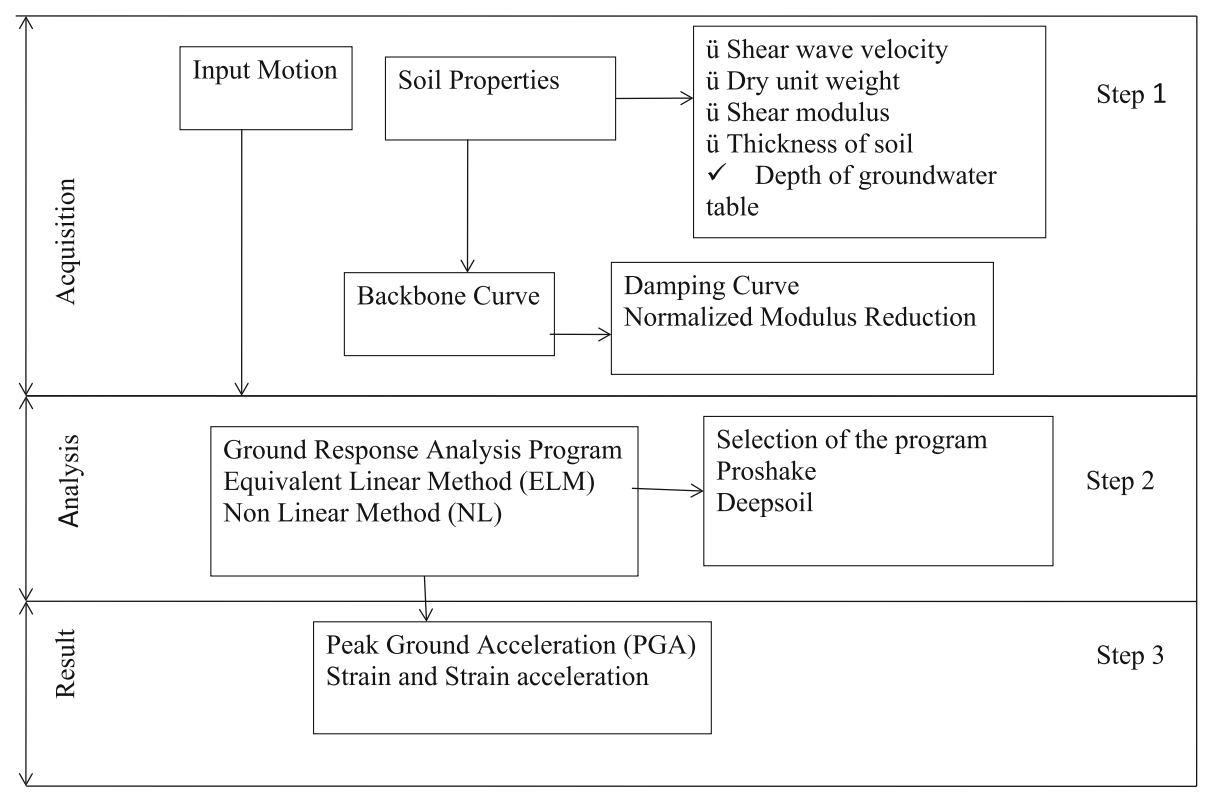

Fig. 9 Steps to be followed for the site response analysis (modified after Anbazhagan 2013; Eko and Eric 2016) 
depositional environment, cementation, and stress history (Hardin and Drnevich 1972; Kramer 1996; Chen et al. 2000; Chang and Han 2017).

\section{Empirical method}

Many researchers have developed empirical relations between surface geology and ground motion parameters. Based on seismic observations, the relationship between surface geology and seismic intensity increments has been developed by various researchers (e.g. Medvedev and Sinityma 1965; Rodriguez-Marek et al. 2001; Mucciarelli et al. 2004; Paudyal et al. 2012; Paudyal et al. 2013). Various correlations has been used to evaluate effect of local soil on earthquake ground motion and the correlation such as: (a) between surface geology and relative amplification, (b) relative amplification based on geotechnical parameters (SPT-N value), (c) average shear wave velocity and relative amplification, and (d) amplification based on surface topography (TC4- ISSMGE 1999).

\section{Experimental method}

The ground vibrating ether naturally or artificially. The main source for the microtremor survey are daily human activities (movements of machinery in factories, motor cars and people walking) and natural phenomena (flow of water in rivers, rain, wind) (Nakamura 1989; Bard 1999; Fritz et al. 2013). According to various authors (e.g. Kanai and Tanaka 1961; Nakamura 1989; Mengistu 2003; Haile 2004) experimental methods generate data based on microtremor measurements and its results used to determine site effects. Nakamura (1989) and Bard (1999) proposed the basis of qualitative arguments about horizontal-to-vertical spectral ratio (HVSR) that can be used to determine site response by providing reliable estimates of resonance frequency and amplification. These ratios reach peak at soft soil sites and correlated with fundamental frequency. Kanai and Tanaka (1961) have explained a theoretical interpretation and practical engineering application of microtremors as a convenient tool for evaluating frequency properties on the ground. In the Main Ethiopia Rift system, many engineering and agricultural activities are practiced on the thick soil which may amplify earthquake ground motion without creating awareness on seismic hazard and risk reduction. As a result, it is recommended that decision makers, engineers and government give due attention on local site effects using microtremor survey.

\section{Numerical methods}

Dynamic response analysis of horizontal soil layers to earthquake is the most basic part in seismic engineering.
It is necessary for estimation of surface acceleration to consider degradation of material properties and/or liquefaction of the soil layer. The numerical methods for $1 \mathrm{D}$ site response analysis including time domain nonlinear (NL) and frequency domain equivalent linear (EQL) have been proposed by (Samuel et al. 2009; Hashash et al. 2010). One-dimensional (1D) analysis (i.e., assuming horizontal soil layers, boundaries of infinite lateral extension and vertically propagating shear waves) proved adequate to model the propagation of the seismic waves through the soil profile (Kramer 1996). The EQL method has been widely used in both research and engineering practice (Kramer and Paulsen 2004; Kaklamanos et al. 2015).

Linear (frequency and time domain) response analysis The linear site response analysis is performed in either frequency or time domain (Schnabel et al. 1972a, 1972b, 1972c; Hashash et al. 2016) using Deepsoil and Proshake computer programs. Furthermore, linear ground response analysis is applicable to estimate linearity of soil properties during earthquake ground motion from recorded or synthetic data.

Non-linear (time domain) response analysis A nonlinear response analysis, which is performed in time domain, the dynamic equation of motion is integrated at each time step and nonlinear soil behavior accurately modeled (Schnabel et al. 1972a, 1972b, 1972c; Lee et al. 2008). However, the non-linear site response analysis is not widely used due to difficulty in performing the analysis and high computational cost. The programs like DEEPSOIL 6.4 and Strata used to analyze non-linear site response analysis of soil profile as reported by (Allen et al. 2009; Hashash et al. 2016), however, this programs are not used to determine local site effect when soil profile is not horizontal.

Equivalent linear (frequency domain) response analysis Equivalent-linear ground response modeling is by far the most commonly utilized procedure in for earthquake engineering (Kramer and Paulsen 2004; Kaklamanos et al. 2015). It combines effect of linear and non-linear soil properties (Idriss 1990). In addition to that, frequency-dependent equivalent linear algorithms proposed to overcome limitation and better simulate nonlinear hysteretic soil response under seismic loading (Sugito et al. 1994; Stark and Olson 1995; Rovelli 1998; Yoshida et al. 2002; Nguyen and Gatmiri 2007; Hashash et al. 2010; Naveen James et al. 2014; Kaklamanos et al. 2015).

According to Schnabel et al. (Schnabel et al. 1972a, 1972b, 1972c; Schnabel et al. 1973) 1-D equivalentlinear site response analysis method used to estimate 
the transformation of earthquake motions as they propagate upward through a soil profile. Finally, the most commonly used equivalent-linear computer code is SHAKE (Schnabel et al. 1972a, 1972b, 1972c) and modified version of SHAKE91 (Idriss and Sun 1992) and SHAKE04.

Two dimensional equivalent linear response analysis The one dimensional site response analysis is useful for level or gently sloping ground with parallel soil layers. The two dimensional analysis can be done both on frequency domain or time domain methods and incorporate the effect of irregular topography that can't be considered in 1D response analysis (Spudich et al, 1996). Analysis can be done using dynamic finite element method by adopting either equivalent linear approach (in frequency domain) or nonlinear approach (in time domain) using numerical modeling software like PLAXIS, FLAC, QUAKE/W for modeling two dimensional dynamic properties of soil Kramer (1996).

\section{Liquefaction and its susceptibility}

Soil liquefaction is the transformation of granular soils from solid state to a liquefied state as a consequence of increased pore water pressure and reduced effective stress during cyclic loading (Marcuson et al. 1977). Liquefaction potential evaluation of soils is an important step in many geotechnical investigations in earthquakeprone regions (Heidari and Andrus 2010; Amoly et al. 2016). As a result, liquefaction can be a potential seismic hazard in the Holocene loose and poorly graded sands and low plastic silts existed at shallow depth $(<20 \mathrm{~m})$ below the water table (Marcuson et al. 1977). Not all soils are susceptible to liquefaction so that certain criteria used to evaluate their susceptibility criteria are historical, geologic, and compositional and state (Kramer 1996).

\section{Historical criteria}

Youd (1984) and Youd (1991) stated that liquefaction occurred in the past may recur in future. Thus, liquefaction case histories can be used to identify specific sites, or more general site conditions, that may be susceptible to liquefaction in future earthquakes (Kramer 1996).

Ambraseys and Barazangi (1989) compiled worldwide data from shallow earthquakes to estimate a limiting epicentral distance and distance to which liquefaction expected with increasing magnitude.

\section{Geological criteria}

According to Youd and Noble (1997) and Youd (1991) soil deposits susceptible to liquefaction are formed within a relatively narrow range of geological environments, hydrological environment and age of a soil deposits. In addition to that, uniform grain size due to geological process which makes loose, fluvial, colluvial and aeolian deposits when saturated are likely to be highly susceptible to liquefaction (Kramer 1996). Finally, new soil deposits (Holocene age) are more susceptible to liquefaction than old (Pleistocene age) soil deposits and it is observed at shallow groundwater depth (Kramer 1996).

\section{Compositional criteria}

The compositional characteristics of excess pore pressure cause high volume change potential tend to be associated with high liquefaction susceptibility. Compositional characteristics which affect susceptibility to liquefaction include particle size, shape and gradation (Ishihara 1984, 1985; Kramer 1996).

\section{State criteria}

A soil fulfills all the criteria for liquefaction susceptibility, yet it may or may not be susceptible to liquefaction. Since liquefaction susceptibility also depends on the initial state of the soil (i.e., stress and density characteristics at the time of the earthquake). The tendency to generate excess pore pressure of a particular soil is strongly influenced by both density and initial stress condition for liquefaction susceptibility (Kramer 1996). In this context, there is no liquefaction history in Ethiopia, but uniform grain size due to geological process makes loose, fluvial, colluvial and particle size, shape and gradation that occurred on the Ethiopian seismic zone prone areas may probably cause liquefaction.

\section{Liquefaction Hazard analysis}

Earthquake-induced liquefaction hazard analysis is an important component of geotechnical earthquake engineering site characterization. Globally, different authors have carried out soil liquefaction potential analysis using several methods (Iwasaki 1982, 1978; Robertson and Campanella 1985; Robertson and Wride 1998; Seed and Idriss 1982; Seed and Idriss 1972; Seed et al. 1985; Youd and Idriss 2001; Seed et al. 1984, 2003; Andrus and Stokoe 2000; Youd et al. 2001). The approaches to be followed for liquefaction potential evaluation (Anbazhagan 2013) and seismic hazard assessment are given in Fig. 10.

As reported by various authors (e.g Hamid et al. 2017; Iwasaki 1982; Seed et al., 1971) the liquefaction hazard, liquefaction potential and probability of liquefaction data for soil profile is produced from geotechnical, hydrogeological and shear wave velocity data. The approaches used for the evaluation of the potential of liquefactions are (Kramer 1996); (i) cyclic stress approach, (ii) cyclic strain approach, (iii) energy dissipation approach, (iv) effective stress-based response analysis approach and (v) probabilistic approach. The cyclic stress approach is 


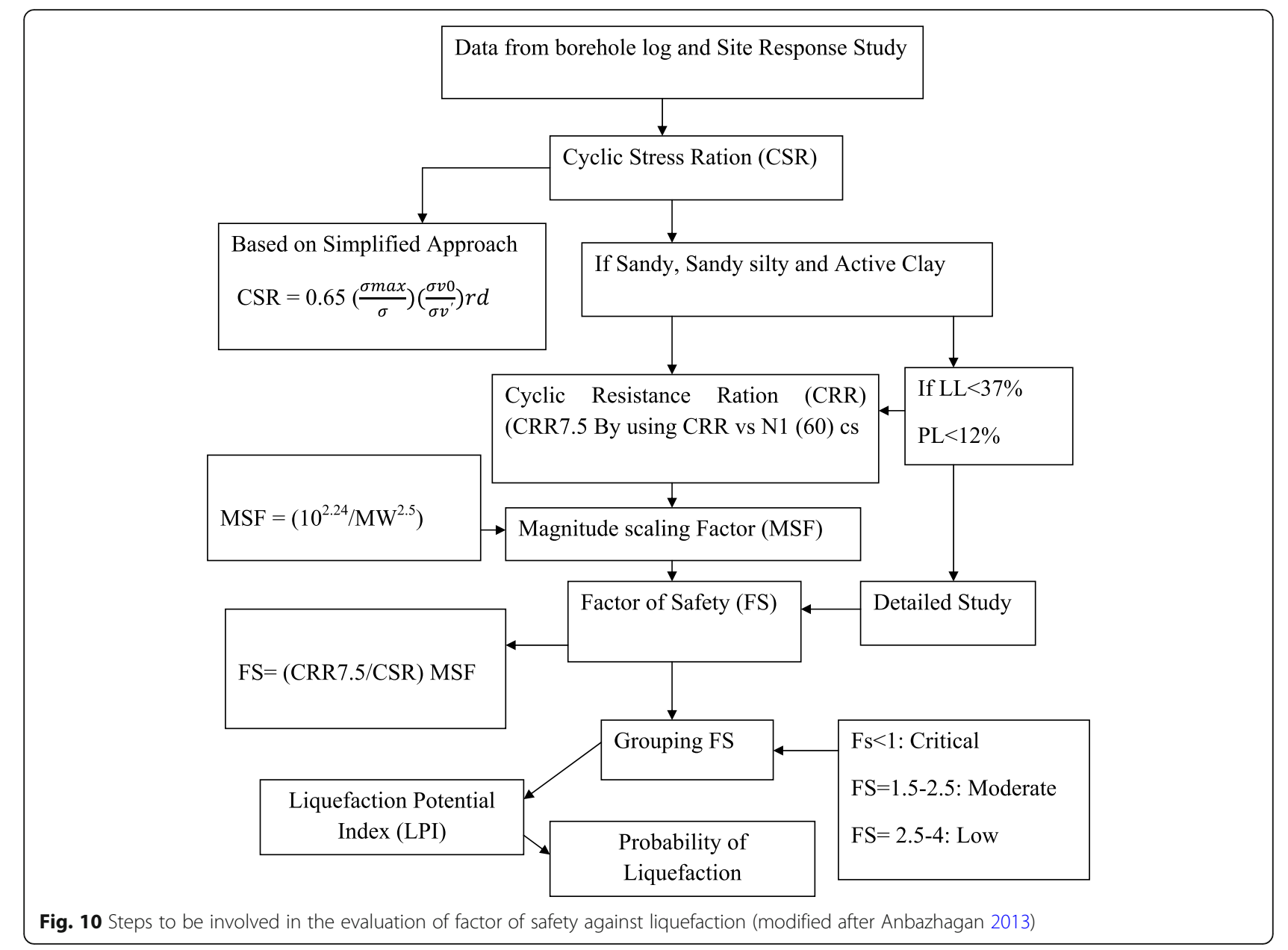

simple and the earthquake-induced loading expressed on the basis of cyclic shear stresses compared to the liquefaction resistance of soil.

The cyclic strain approaches need to determine large number of factors from laboratory test that influence the cyclic stresses required to produce liquefaction (Kramer 1996). The primary advantage of the cyclic strain approach derives from strong relationship between pore pressure generation and cyclic strain amplitude; however, the cyclic strain approach is not commonly used as the cyclic stress approach in geotechnical earthquake engineering practice (Kramer 1996). This is due to cyclic strains are considerably more difficult to predict accurately than cyclic stresses. The dissipated energy and effective stress based response analysis approach is experimental and used to complement with cyclic stress and cyclic strain approach to increase accuracy of the data, but they cannot be used alone in geotechnical earthquake engineering (Kramer 1996). Finally, probabilistic approach used to address potential sources of uncertainty in both seismic loading and resistance of liquefaction problems, but it is not commonly used in liquefaction potential evaluation (Kramer 1996). As a close, cyclic stress approach is simple, robust and reliable to model earthquake induced stresses within the ground because it can be determined from field and laboratory tests (Kramer 1996). Also, many design charts and correlations were developed based on cyclic stress approach for the estimation of liquefaction resistance of soils based on laboratory as well as in-situ tests.

\section{Cyclic stress approach}

The cyclic stress approach is generally widely used liquefaction potential evaluation for earthquake engineering. In the cyclic stress approach, liquefaction potential hazard analysis evaluated on five stages (Kramer 1996; Youd et al. 2001): (i) evaluation of earthquake loading expressed as cyclic stress ratio (CSR), (ii) evaluation of soil strength against earthquake loading expressed as cyclic resistance (CRR), (iii) determination of factory of safety (FS), magnitude scaling factor (MSF) and (vi) seismic factors. The most widely used cyclic tress approach, simplified procedure, originally proposed by for evaluating liquefaction resistance of soils. Also, Seed and Idriss 
(1982) and Seed et al. (1985) modified the simplified procedure for evaluating liquefaction resistance of soils. Finally, adjusted, modified and evaluated by Seed et al. (2001), Youd et al. (2001) and Idriss and Boulanger (2004).

\section{Evaluation of cyclic stress ratio (CSR)}

The cyclic characteristics of a soil (CSR) is the average cyclic shear stress $\left(\tau_{\text {av }}\right)$ soils due to cyclic or earthquake loading to the initial vertical effective stress $\left(\sigma_{0}\right)$ acting on the soil layer (Liu et al. 2001; Rahman 2019). It also account depth of the soil layer, depth of groundwater level and intensity of earthquake shaking or other cyclic loading phenomena. The simplified procedure that are widely used to estimate CSR developed in the field considering an earthquake loading and a depth $\mathrm{z}$ from the ground surface by Seed and Idriss (1971).

\section{Evaluation of cyclic resistance ratio (CRR)}

The cyclic resistance of a soil represented by cyclic resistance ratio (CRR) determined in the laboratory as well as in-situ or field test (Kramer 1996; Rahman 2019. However, in-situ stress state cannot be established accurately in the laboratory because traditional drilling can disturb soil samples and give meaningful results. In addition, the costs of laboratory tests are sometimes beyond the budget and scope of the most engineering projects. As a result, to avoid difficulties associated with sampling and laboratory testing costs, Youd et al. (2001) recommended four in situ test methods for liquefaction potential assessment: ii) standard penetration test (SPT); ii) cone penetration test (CPT); iii) in-situ shear wave velocity measurement (Vs); and iv) Becker penetration test (BPT).

The cyclic resistance ratio for $\mathrm{Mw}=7.5$ earthquake (CRR7.5) are determined from overburden stress corrected standard penetration test (SPT) resistance of equivalent clean sand, (N1) 60cs (Seed et al. 2001, Youd et al. 2001, Idriss and Boulanger 2004). Furthermore, CRR evaluated from overburden stress corrected cone penetration test $(\mathrm{CPT})$ resistance of equivalent clean sand, (qc1N) cs (Robertson and Wride 1998) and overburden stress corrected shear wave velocity of equivalent clean sand, Vs1 (Andrus and Stokoe 1997; Vungania et al. 1999; Andrus and Stokoe 2000). Finally, CRR analyzed overburden stress using corrected Becker penetration test (BPT) resistance, $\mathrm{N}_{\mathrm{BC}}$ (Harder 1997).

The standard penetration resistance is widely used to evaluate liquefaction potential (Sonmez, 2003; Seed et al. 1985, 2001; Bennett et al. 1984; Chen et al. 2000 Youd et al. 2001; Seed et al. 2003 Idriss and Boulanger 2004, Sonmez et al. 2008).

According to Robertson and Campanella (1985) CRR can be estimated based on cone penetration test (CPT) with intrinsic difficulties and poor repeatability of the SPT results. This procedure later updated by Stark (1995). The main advantage of the CPT used to generate nearly continuous penetration resistance profiles of strata, more consistence and repeatable than the results of SPT (Youd et al. 2001). The CRR also estimated from the field measurement of shear wave velocity as reported by Andrus and Stokoe (1997, 2000). The benefits of using shear wave velocity are: i) the measurement are possible in hard soils where SPT and CPT are difficult to penetrate or to collect undisturbed samples such as gravelly soils or at the site where SPT and CPT may not be permitted; ii) shear wave velocity of soil materials are directly related to the small-strain shear modulus; iii) 3) the shear wave velocity used for estimating dynamic soil response and soil-structure interaction analyses (Youd et al. 2001).

The SPT and CPT used to estimate the liquefaction resistance of non-gravelly soils. However, the penetration resistance measurements by SPT and CPT are not generally consistent in gravelly soils because large gravels may interfere the normal deformation of soils around the penetrometer and misleadingly increase the penetration resistance. Becker penetration test (BPT) recommended by Youd et al. (2001) used to estimate the penetration resistance in gravelly soils. Though, the criteria for liquefaction resistance (i.e., cyclic resistance ratio, CRR) evaluation using standard penetration test (SPT) blow counts have been rather robust over the years (Youd et al. 2001).

\section{Magnitude scaling factor (MSF)}

A magnitude scaling factor (MSF) used to adjust CRR7.5 to determine CRR for other earthquake magnitudes. In addition to that, the CRR should be adjusted for the value of earthquake magnitude smaller or larger than 7.5 (Rahman 2019). Several researchers (e.g Seed and Idriss 1982, Ambraseys 1988, Arango 1996, Andrus and Stokoe 1997, Youd and Noble 1997) has forwarded conservative values when earthquake magnitude is smaller or larger than 7.5 for the correction of MSF. The NCEER 1998 (Youd et al. 2001) recommended MSF, which was proposed by Boulanger et al. (1995).

\section{Determination of factor of safety}

In simplified procedure, the factor of safety (FL) against liquefaction is defined in terms of CRR, CSR and MSF given by (Seed et al., 1971; Anbazhagan and Premalatha 2004).

\section{Seismic factors}

The simplified procedure needs earthquake magnitude and peak ground acceleration. as a input for the evaluation of liquefaction resistance of soils (Rahman 2019). 


\section{Liquefaction potential index (LPI)}

The factor of safety (FL) alone is not a sufficient parameter for evaluation of liquefaction and damage potential at any site. However, the thickness, depth of liquefiable layer and factor of safety are very important inputs for damage potential of liquefaction Iwasaki et al. (1978). The liquefaction potential index (LPI) is very popular tool to evaluate potential for liquefaction to cause foundation damage due to inclusion of the thickness, depth of the liquefiable layer and the factor of safety Iwasaki (1978, 1982).

The general approach used in the seismic hazard analysis, microzonation and liquefaction potential is shown in the Fig. 11. The probability of liquefaction-induced ground disruption determined from computed values of liquefaction potential index (LPI) at each location of borehole (Papathanassiou 2008). Ethiopia is situated in seismic prone areas, but many engineering activities are practiced on it without prior information about liquefaction hazard evaluation. Liquefaction potential assessment of Tendaho dam based on the grain size analysis revealed that loosely deposited alluvium foundation liquefy under earthquake loading and endangering the stability of dam (Seged and Haile 2010). As a result, Ethiopia constructing projects like dams, roads, railway, power plant, electric transmission cables, bridges, industrial part and building structures on the heart of Ethiopian seismic zone without considering seismic analysis and liquefaction potential evaluation. So, any projects that are built on the seismic active areas of Ethiopia give attention to make the environment safe.

\section{Conclusions}

In the seismic hazard analysis of Ethiopia, getting strong recorded ground motion data are not possible; however, with the knowledge of earthquake source and path effects, synthetic ground motion simulations data are used for engineering purpose. The individual earthquakes with different magnitude usually affect certain local areas in Ethiopia. So far, no comprehensive analysis of losses due to such hazards has made to justify their economic, social and environmental significance at local and regional level. As a result, damage resulting from seismic hazards has not generally been recognized as a problem of national importance. This is because governments give full attention on the drought, erosion and famine of the Ethiopia. Hence, the earthquake hazards and risk mitigation of the Ethiopia should be concerned by decision makers and engineers. In order to address earthquake related primary and secondary damage effect on the country, they need research activities and development work in Ethiopia. In this regard, considering the scale of the earthquake problems and socio-economic development in the country, the on-going research on earthquake is very insignificant. There is a robust requirement to initiate research on: (a) earthquake hazard analysis and loss assessment, (b) ground motion prediction and monitoring, (c) cost-effective earthquake mitigation (remedial) measure, (d) ground response analysis, (e) developing site specific seismic code of Ethiopia at local scale (f) liquefaction potential evaluation and (h) creating outreach and awareness to the people.

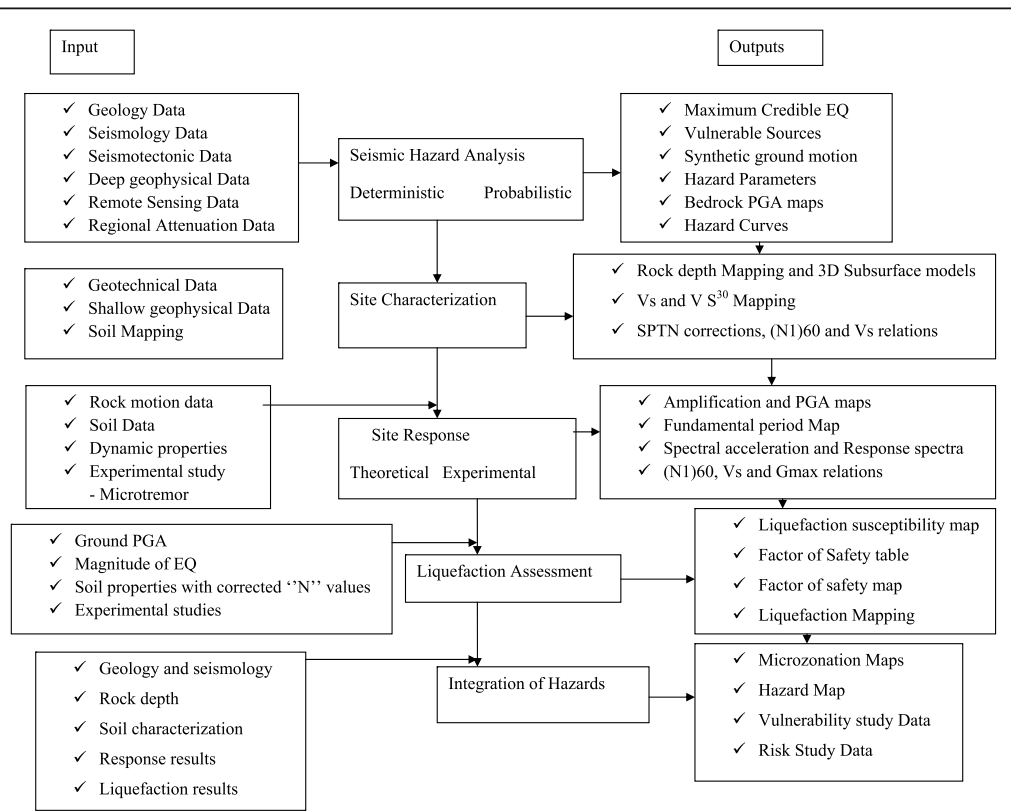

Fig. 11 Steps to be followed for seismic hazard assessment and microzonation studies (Sitharam and Anbazhagan 2008) 
For better understanding of seismic hazard initiations, improving the quality of seismic hazard mapping, microzonation and predictions, all past and recent earthquakes history, which have occurred in a specified period of time and space have to be mapped. This should be achieved by careful analyzing of earthquake catalogue, identifying active fault source, local conditions and liquefaction potential evaluation. Furthermore, the cause or source of each earthquake should be studied as this will improve our knowledge on the triggering mechanisms and controlling parameters of earthquake. Evaluation of the fault or source, distance and local condition mechanisms so far reported were based on the numerical modeling and field observations of features indicative of failure mechanisms and monitoring. Earthquakes are geological and needs proper understanding of the geological setting (lithological and structural), topography characteristics, slope analysis, hydrological condition (surface and groundwater), geomorphological processes, geophysical properties and engineering geological parameter for understanding the occurrence of earthquake as well as for designing appropriate mitigation measures of earthquake. Generally, earthquake depends on source, path and site conditions. As a result, careful analysis should be given before doing any projects in seismically prone areas. However, experimental studies shown that more than source and path (distance), geology can change incoming seismic waves and controls ground motion parameters like peak ground acceleration (PGA), peak ground velocity (PGV) and peak ground distance (PGD). So, based on this view, more attention should be given on local site effects or geology like dynamic properties of soil (shear wave velocity, shear modulus and standard penetration resistance) and site response analysis, liquefaction potential to control seismic hazard as well as risk mitigation on the Ethiopia. Also, based on the report of Ethiopia, earthquake is occurred due to faults, but type of faults, number of active faults, orientation of the fault, slip rate, fault length and directivity pulse are not known and needs further assessments using multi-disciplinary approach. In addition, path effects are determined by ground motion prediction equation (GMPE). However, no work is reported due to non-availability of registered earthquake data in the Ethiopia. As a result, this needs to develop ground motion prediction equation for assessment of path effects and mitigate seismic hazard using numerical modelling. Ethiopia is embarking massive construction like dams, roads, bridges, power plant and electric power lines, railway and multi-story buildings in the country. Many of these projects pass and constructed on the heart of Main Ethiopia Rift system of potentially unstable areas. Surprisingly, this all projects built in the seismically active region without earthquake hazard study, therefore, a strong need to evaluate the earthquake condition and liquefaction potential evaluation to make our environment safe.

\section{Recommendations}

Based on the thorough review of the literature, the following recommendation is forwarded for further earthquake research in the Main Ethiopia Rift System, escarpment and Afar depression of Ethiopia;

- Characterizing local site effects using shear wave velocity, standard penetration resistance and ground site response analysis.

- Earthquake related problems such as liquefaction and slope instability is to be mapped.

- Earthquake-groundwater interaction should be analyzed.

- Deterministic Seismic Hazard Assessment (DSHA) is to be used for the design of critical infrastructure.

- Updating seismic design code of Ethiopia by incorporating slope, topography and soil thickness.

- Large infrastructure projects such as dams, bridges, power-plants, railway structures need to be governed by separate seismic code which is more stringent than the building code.

- Site-specific zoning including local site effect should be developed for metropolitan areas of Ethiopia.

- Geophysical survey should be needed to map deep seated geological structures to characterize the source.

\section{Abbreviations}

1D: One Dimensional; ASTER: Advanced Space borne Thermal Emission and Reflection Radiometer; BF: Border faults; BPT: Becker penetration test; CPT: Cone Penetration Test; CRR: Cyclic Resistance; CSR: Cyclic Stress Ratio; DEM: Digital Elevation Model; DSHA: Deterministic Hazard Assessment; EQL: Frequency domain equivalent linear; ES EN1998: 2015: Ethiopian Seismic Building Code; FS: Factory of Safety; GIS: Geographic Information System; Gmax: Shear modulus; GMPE: Ground Motion Prediction Equations; HVSR: Horizontal-to-Vertical Spectral Ratio; LPI: Liquefaction Potential Index; M/S: Meter Per second; MASW: Multichannel Analysis of Surface Waves; MCE: Maximum credible earthquake; MSF: Magnitude Scaling Factor; Mw: Moment of Magnitude; NEHRP: Natural Earthquake Hazard Reduction Program; NL: Time domain nonlinear; PGA: Peak ground acceleration; PGD: Peak ground distance; PGV: Peak Ground Velocity; PSHA: Probabilistic Seismic Hazard Assessment; SPT: Standard Penetration Test; SRTM: Shuttle Radar Topographic Mission; Vs: Shear Wave Velocity; $V^{30}$ : Average shear wave velocity; WFB: Wonji Fault Belt

\section{Acknowledgements}

The author would like to thank my principal advisor Dr., Kifle Woldearegay, Mekelle University, for his very constructive comments to the draft paper. Without the encouragement of Dr., Matebie Meten, Department of Geology, Addis Ababa Science and Technology University, this review paper would not have been made and the author would like to acknowledge for the support.

\section{Data source}

Not applicable.

Authors' contributions

The author(s) read and approved the final manuscript. 


\section{Funding}

Not available.

\section{Competing interests}

The authors declare that we do not have any financial or non-financial competing interests with any individual or institution.

\section{Author details}

'Department of Geology, College of Applied Science, Addis Ababa Science and Technology University, P.O.Box. 16417, Addis Ababa, Ethiopia. ${ }^{2}$ School of Earth Science, Mekelle University, P.O.Box. 231, Mekelle, Ethiopia. ${ }^{3}$ Department of Geology, College of Applied Science, Addis Ababa Science Technology and University, P.O.Box 16417, Addis Ababa, Ethiopia.

Received: 17 September 2020 Accepted: 23 December 2020 Published online: 19 April 2021

\section{References}

Abrahamson N, Silva W (2008) Summary of the Abrahamson and Silva NGA ground-motion relations. Earthquake Spectra 24(1):67-97 https://doi.org/10. $1193 / 1.2924360$

Adel M, Cortez-Flores (2004) Site response of the 2001 southern Peru earthquake, Washington state university, and unpublished master thes

Adel ME, Mohamed HE, Abdel Hafiez MA, Taha (2013) Estimating the near-surface site response to mitigate earthquake disasters at the October 6th city, Egypt, using HVSR and seismic techniques, NRIAG. J Astronomy Geophysics 2:146165

Agostini A, Bonini M, Corti G, Sani F, Mazzarini F (2011) Fault architecture in the Main Ethiopian rift and comparison with experimental models: implications for rift evolution and Nubia-Somalia kinematics. Earth Planet Sci Lett 301(34):479-492

Akhila M, Ghosh C, Neelima Satyam D (2012) Detailed ground response analysis at Park Hotel in Kolkata City, India, 15 WCEE, Lisboa

Aki K (1998) Local site effects on strong ground motion, earthquake engineering and soil dynamics II- Recent Advances in Ground Motion Evaluation, Park City, Utah

Aki K, Richards PG (1980) Quantitative seismology. Freeman and Co., New York

Alan Y, Susan E, Hough MJ, Abrams HM, Wills CCJ, Gerry WS (2008) Site characterization using integrated imaging analysis methods on satellite data of the Islamabad, Pakistan, region. Bull Seismol Soc Am 98(6):2679-2693 https://doi.org/10.1785/0120080930

Alemu BE, Worku A, Wassie GM, Habtesellasie GT (2018) Ground Response Analysis of Representative Sites of Hawassa City. In: Geotechnical Earthquake Engineering and Soil Dynamics V: Seismic Hazard Analysis, Earthquake Ground Motions, and Regional-Scale Assessment. American Society of Civil Engineers, Reston, pp 422-434

Allen RM, Gasparini P, Kamigaichi O, Bose M (2009) The status of earthquake early warning around the world: An introductory overview. Seismol Res Lett 80(5): 682-693

Ambraseys NN (1988) Engineering seismology. Earthq Eng Struct Dyn 17:1-105 https://doi.org/10.1002/eqe.4290170102/abstract

Ambraseys NN, Barazangi M (1989) The 1759 earthquake in the Bekaa Valley: implications for earthquake hazard assessment in the Eastern Mediterranean region. J Geophys Res Solid Earth 94(B4):4007-4013

Ambraseys NN, Douglas J (2003) Near-field horizontal and vertical earthquake ground motions. Soil Dyn Earthq Eng 23(1):1-18 https://doi.org/10.1016/ S026-7261(02)00153-7

Amoly RS, Ishihara K, Bilsel H (2016) The relation between liquefaction resistance and shear wave velocity for new and old deposits. Soils Found 56(3):506-519

Anbazhagan P (2013) Method for Seismic Microzonation with Geotechnical Aspects. Disaster Adv 6(4) A review paper

Anbazhagan P, Mog K, Rao KN, Prabhu NS, Agarwal A, Reddy GR, Das SK (2019) Reconnaissance report on geotechnical effects and structural damage caused by the 3 January 2017 Tripura earthquake, India. Nat Hazards 98(2): 425-450

Anbazhagan P, Neaz SM, Parihar A (2013) Influence of rock depth on site classifications in Asia Pacific region, Natural Hazard Review, ASCEonline. https://doi.org/10.1061/\%28ASCE\%29NH.15276996.0000088

Anbazhagan P, Premalatha K (2004) Microzonation of liquefaction factor of safety of Chennai City, division of soil mechanics and foundation engineering. Anna University, Chennai
Anbazhagan P, Sitharam TG (2008) Site characterization and site response studies using shear wave velocity. J Seismol Earthquake Eng 10(2):53-67

Anbazhagan P, Sitharam TG, Vipin KS (2009) Site classification and estimation of surface level seismic hazard using geophysical data and probabilistic approach. J Appl Geophys 68:219-223

Anbazhagan P, Sreenivas M, Ketan B, Moustafa SSR, Al-Arifi NS (2016) Selection of ground motion prediction equations for seismic hazard analysis of peninsular India. J Earthq Eng 20(5):699-737

Anbazhagan P, Thingbaijam KKS, Nath SK, Narendara KJN, Sitharam TG (2010) Multi-criteria seismic hazard evaluation for Bangalore city, India. J Asia Earth Sci 38:186-198

Andrus RD, Stokoe KH (1997) Liquefaction resistance based on shear wave velocity. In: Proceeding of NCEER workshop on evaluation of liquefaction resistance of soils. National Center for Earthquake Engineering Research, Sate University of New York, and Buffalo, pp 89-128

Andrus RD, Stokoe KH (2000) Liquefaction resistance of soils from shear-wave velocity. J Geotech Geoenviron 126(11):1015-1025

Arango I (1996) Magnitude scaling factors for soil liquefaction evaluations. Geotech Eng 122(11):929-936

Asfaw $L$ (1982) Site amplification at the Western escarpment of the east African rift system near Addis Abeba, letters to the editor. Bull Seismol Soc Am 72(1): 327-329

Asfaw L (2003) Intensity Reports since P. Gouin's Book, Unpublished Report, Obtained through personal communications

Asfaw LM (1990) Implication of shear deformation and earthquake distribution in the East African Rift between $4 \mathrm{~N}$ and 6 N. J Afr Earth Sci (Middle East) 10(4): $745-751$

Asfaw LM (1998) Environmental hazard from fissures in the Main Ethiopian Rift. J Afr Earth Sci 27(3-4):481-490

Ashford SA, Sitar N (1997) Analysis of topographic amplification of inclined shear waves in a steep coastal bluff. Bull Seismol Soc Am 87(3):692-700

Atkinson JH, Sallfors G (1991) Experimental determination of soil properties. Proc 10th ECSMF 3:915-956

Avouac JP, Meng L, Wei S, Wang T, Ampuero JP (2015) Lower edge of locked Main Himalayan Thrust unzipped by the 2015 Gorkha earthquake. Nat Geosci 8(9):708-711

Ayalew L, Yamagishi H, Reik G (2004) Ground cracks in Ethiopian Rift Valley: facts and uncertainties. J Eng Geol 75:309-324

Ayele A (2000) Reassessment of source parameters for three earthquakes parameters in the east African east system from historical seismograms and bulletins. Ann Geofis 43(1)

Ayele A (2017) Probabilistic seismic hazard analysis (PSHA) for Ethiopia and the neighboring region. J Afr Earth Sci:134-265

Bajaj K, Anbazhagan P (2019a) Comprehensive amplification estimation of the Indo Gangetic Basin deep soil sites in the seismically active area. Soil Dyn Earthq Eng 127:105855

Bajaj K, Anbazhagan P (2019b) Spatial variability of shear wave velocity in the deep and active indo-Gangetic Basin. Geophys J Int

Baker JW (2008) An Introduction to Probabilistic Seismic Hazard Analysis (PSH) Version 1.3

Baker JW (2013) Introduction to probabilistic seismic hazard analysis, White paper version 2.0.1

Bard PV (1999) Microtremor measurements: a tool for site effect estimation? In: The effects of surface geology on seismic motion, Irikura, Kudo, Okada and Sasatani (eds). Balkema, Rotterdam, pp 1251-1278

Bennett MJ, McLaughlin PV, Sarmiento JS, Youd TL (1984) Geotechnical investigation of liquefaction sites, Imperial Valley, California. US Geological Survey Open File Report, pp 84-252

Bolt BA (1999) Estimating seismic ground motion. Earthquake Spectra 15(2):187198

Bommer JJ, Efri M, Akkar S (2012) Consistent source-to-site distance metrics in ground-motion prediction equations and seismic source models for PSHA. Earthquake Spectra 28(1):1-15

Boore DM (2003) Simulation of ground motion using the stochastic method. Pure Appl Geophys 160:635-675

Boore DM (2004) Can site response be predicted? J Earthq Eng 8(spec01):1-41 Boore DM, Atkinson GM (2008) Ground-motion prediction equations for the average horizontal component of PGA, PGV, and 5\%-damped PSA at spectral periods between $0.01 \mathrm{~s}$ and $10.0 \mathrm{~s}$. Earthquake Spectra 24(1):99-138 https:// doi.org/10.1193/1.2830434 
Boore DM, Joyner WB, Fumal TE (1997) Equations for estimating horizontal response spectra acceleration from Western North American earthquakes: A summary of recent work. Seismol Res Lett 68(1):29-26

Borcherdt RD (1970) Effects of local geology on ground motion near San Francisco Bay. Bull Seismol Soc Am 60(1):29-61

Borcherdt RD, Glassmoyer G (1970) On the characteristics of local geology and their influence on ground motions generated by the Loma Prieta earthquake in the San Francisco Bay region, California. Bull Seismol Soc Am 82(2):603641

Bouckovalas GD, Gazetas G, Papadimitriou AG (1999) Geotechnical aspects of the 1995 Aegion, Greece, earthquake. In: Proceedings 2nd International Conference on Geotechnical Earthquake Engineering, Lisbon, 2, pp 739-748

Bouckovalas GD, Papadimitriou AG (2005) Numerical evaluation of slope topography effects on seismic ground motion. Soil Dyn Earthq Eng 25(7-10): $547-558$

Boulanger RW, Idriss IM, Mejia LH (1995) Investigation and evaluation of liquefaction related ground displacements at Moss Landing during the 1989 Loma Prieta Earthquake. Center for Geotechnical Modeling, Department of Civil \& Environmental Engineering, University of California, Davis

Brown GE (2001) Division of civil and Mechnaical system, Network for earthquake engineering simulation (NEES)

BSSC (2015a) 2015 Edition NEHRP recommended seismic provisions for new buildings and other structures, FEMA P-1050-1 (provisions and commentary), Washington, D.C

BSSC (2015b) NEHRP recommended seismic provisions for new buildings and other structures, Part 1 (provisions) and part 2 (commentary), FEMA P-1050-1, building seismic safety council, Federal Emergency Management Agency, Washington, D.C Available from http://www.fema.gov/media-library-data/2 0130726-1730-25045 1580/femap_750.pdf

Campbell KW, Bozorgnia Y (2008) NGA ground motion model for the geometric mean horizontal component of PGA, PGV, PGD and 5\% damped linear elastic response spectra for periods ranging from 0.01 to $10 \mathrm{~s}$. Earthquake Spectra 24(1):139-171 https://doi.org/10.1193/1.2857546

Casto DW, Luke B, Calderon-Macias C, Kaufmann R (2009) Interpreting SurfaceWave Data for a Site with Shallow Bedrock. J Environ Eng Geophys 14(3): 115-127 https://doi.org/10.2113/JEEG14.3.116

Castro G, Christian JT (1976) Shear Strength of Soils and Cyclic Loading, J Geotechincal Engineering, ASCE (102) GT9, pp 887-894

Celebi M (1987) Topographical and geological amplifications determined from strong-motion and aftershock records of the 3 march 1985 Chile earthquake. Bull Seismol Soc Am 77:1147-1167

Chang GS, Han S (2017) GIS-based regional assessment of seismic site effects considering the spatial uncertainty of site-specific geotechnical characteristics in coastal and inland urban areas. Geomatics Nat Hazards Risk 8(2):1592-1621 https://doi.org/10.1080/19475705.2017.1364305

Chang SW, Bray JD, Seed RB (1996) Engineering Implications of Ground Motions from the Northridge Earthquake. Bull Seismol Soc Am 86(1):270-288 Part B Suppl

Chen CJ, Juang CH (2000) Calibration of SPT and CPT-based liquefaction evaluation methods. In: Mayne P, Hryciw R (eds) Innovations and applications in geotechnical site characterization, vol 97. Geotechnical special publication, ASCE, Reston, pp 49-64

Chen KM, Huang Y, Zhang J, Norman A (2000) Microwave life-detection systems for searching human subjects under earthquake rubble or behind barrier. IEEE Trans Biomed Eng 47(1):105-114

Chen WF, Scawthorn C (2003) Earthquake engineering handbook, 3rd edn. CRC Press LLC, Boca Raton

Chiou BJ, Youngs RR (2008) An NGA model for the average horizontal component of peak ground motion and response spectra. Earthquake Spectra 24(1):173-215

Cornell CA (1968) Engineering seismic risk analysis. Bull Seismol Soc Am 58(5): 1583-1606

Cox RT, Hill AA, Larsen D, Holzer T, Forman SL, Noce T, Gardner C, Morat J (2007) Seismotectonic implications of sand blows in the southern Mississippi embayment. Eng Geol 89:278-299 https://doi.org/10.1016/j.enggeo.2006.11. 002

Darendeli MB (2001) Development of a new family of normalized modulus reduction and material damping curves. Doctor of Philosophy. University of Texas at Austin

Dikmen Ü (2009) Statistical correlations of shear wave velocity and penetration resistance for soils. J Geophys Eng 6(1):61-72
Dobry R, Borcherdt CCB, Idriss IM, Joyner WB, Martin GR, Power EE, Seed RB (2000) New site coefficients and site classification system used in recent building seismic code provisions. Earthquake Spectra 16(1):41-67

Dobry R, Vucetic M (1987a) State of the art report: dynamic properties and response of soft clay deposits. Proc Int Symp Geotech Eng Soft Soils Mexico City 2:51-87

Dobry R, Vucetic M (1987b) Dynamic properties and seismic response of soft clay deposits, Proceedings, International Symposium on Geotechnical Engineering of Soft Soils, Mexico City, Published by Sociedad Mexicana de Mecanica de Suelos, AC, vol 2, pp 49-85

Douglas J (2001) A critical reappraisal of some problems in engineering seismology. Phd Dissertation, University of London

Douglas J (2003) Earthquake ground motion estimation using strong-motion records: a review of equations for the estimation of peak ground acceleration and response spectral ordinates. Earth-Sci Rev 61:43-104

Eko Rl, Eric Y (2016) Comparison of Equivalent Linear and Non Linear Methods on Ground Response Analysis: Case Study at West Bangka Site. J PengembanganEnergiNuklir 18(1):23-29

Elin AO, Sigurdur E, Bjarni B (2017) Tool for analysis of multichannel analysis of surface waves (MASW) field data and evaluation of shear wave velocity profiles of soils. Can Geotech J 55:217-233 https://doi.org/10.1139/cgj-20160302

Enke DL, Tirasirichai C, Luna R (2008) Estimation of earthquake loss due to bridge damage in the St. Louis metropolitan area. II: Indirect losses. Nat Hazards Rev 9(1):12-19

Esteva L (1969) Seismic risk and seismic design decisions. In: Proceedings of MIT symposium on seismic Design of Nuclear Power Plants, Cambridge, MA

Eurocode-8 (2003) BS-EN 1998-1, design of structures for earthquake resistance, part 1: general rules, seismic actions and rules for buildings. European Committee for Standardization, Brussels

Fantahun A (2016) Magnitude 4.3 earthquake strikes Awassa. Ethiopia Obs http:// www.ethiopiaobserver.com/2016/01/earthquake-strikes-awassa/

Fardin J, Mohammad M, Shahrabi HFJ (2015) On the role of topographic amplification in seismic slope instabilities. J Rock Mech Geotech Eng 7:163170

Farr TG, Kobrick M (2000) Shuttle radar topography Mission produces a wealth of data. Eos Trans AGU 81:583-585

Fiore VD (2010) Seismic site amplification induced by topographic irregularity: results of a numerical analysis on 2D synthetic models. Eng Geol 114:109115

Fritz HM, Hillaire JV, Molière E, Wei Y, Mohammed F (2013) Twin tsunamis triggered by the 12 January 2010 Haiti earthquake. Pure Appl Geophys 170(9):1463-1474

Gashaye Z (2018) An investigation into the ground motion amplification potential of selected sites of Addis Ababa City. Unpublished MSc thesis, Addis Ababa

Gazetas G, Kallou PV, Psarropoulos PN (2002) Topography and soil effects in the M s 5.9 Parnitha (Athens) earthquake: the case of Adames. Nat Hazards 27(12):133-169

Gouin P (1976) Seismic zoning in Ethiopia. Bulletin of the Geophysical Observatory; no. 17

Gouin P (1979) Earthquake History of Ethiopia and the Horn of Africa. International Development Research Centre (IDRC), Ottawa, p 258

Graves RW (1996) Simulating realistic earthquake ground motions in regions of deep sedimentary basin. Proc. of eleventh world Conf. On earthquake engineering (Acapulco, Mexico) CD-ROM, no. 1932

Haile M (2004) Seismic microzonation for the city of Addis Ababa by using microtremors, 13th world conference on earthquake engineering Vancouver, B.C., Canada

Hamid B, Youcef B, Mohamed T (2017) Liquefaction hazard mapping in the city of Boumerdès, Northern Algeria. Bull EngGeol Environ https://doi.org/10. 1007/s10064-017-1137-x

Harder LF (1997) Application of the Becker penetration test for evaluating the liquefaction potential of gravelly soils. In: Proceeding of NCEER workshop on evaluation of liquefaction resistance of soils. National Center for Earthquake Engineering Research, State University of New York, Buffalo, pp 129-148

Hardin BO, Drnevich VP (1972) Shear modulus and damping in soils: measurement and parameter effects. J Soil Mech Found Div ASCE 98(6):603-624

Harmsen C (1997) Determination of site amplification in the Los Angeles urban area from inversion of strong-motion records. Bull Seismol SocAm 87:866887 
Hartzell S, Carver D, Williams RA (2001) Site Response, Shallow Shear-Wave Velocity and Damage in Los Gatos, California, from the 1989 Loma Prieta Earthquake. Bull Seismol Soc Am 91(3):468-478

Hashash YM, Phillips C, Groholski DR (2010) Recent advances in non-linear site response analysis. Fifth International Conference on Recent Advances in Geotechnical Earthquake Engineering and Soil Dynamics and Symposium in Honor of Professor I.M. Idriss, In, pp 1-22 https://doi.org/10.1016/j.soildyn. 2008.12

Hashash YMA, Musgrove MI, Harmon JA, Groholski DR, Phillips CA, Park D (2016) DEEPSOIL 6.1, User Manual. Board of Trustees of University of Illinois at Urbana Champaign, Urbana, IL

Heidari T, Andrus RD (2010) Mapping liquefaction potential of aged soil deposits in Mount Pleasant, South Carolina. Eng Geol 112:1-12

Hofstetter R, Beyth M (2003) The Afar depression: interpretation of the 1960-2000 earthquakes. Geophys J Int 155:715-732

IBC (2009) International Building Coden International Code Council, Washington

Idriss I, Sun J (1992) SHAKE91: a computer program for conducting equivalent linear seismic response analyses of horizontally layered soil deposits (User's manual). University of California Davis, Davis

Idriss IM (1990) Response of soft soil sites during earthquakes. Proc. Memorial Symposium to Honor Professor H. B, Seed, Berkeley, California

Idriss IM, Boulanger RW (2004) Semi-empirical procedures for evaluating liquefaction potential during earthquakes. In: 11th International Conference on Soil Dynamics and Earthquake Engineering, and 3rd International Conf. on Earthquake Geotechnical Engineering, Berkeley, pp 32-56 https://doi.org/ 10.1016/j.soildyn.2004.11.023

Idriss IM, Boulanger RW (2008) Soil liquefaction during earthquakes. Earthquake Engineering Research Institute

Ishihara K (1982) Evaluation of soil properties for use in earthquake response analysis

Ishihara K (1984) Post-earthquake failure of a tailings dam due to liquefaction of the pond deposit, Proceedings, International Conference on Case Histories in Geotechnical Engineering, University of Missouri, StLouis, vol 3, pp 11291143

Ishihara K (1985) Stability of natural deposits during earthquakes, proceedings, 11th international conference on soil mechanics and foundation engineering, 1, pp 321-376

Ishihara K (1993) Liquefaction and flow failure during earthquakes. Géotechnique 43(3):351-415

Ishihara K (1997) Geotechnical aspects of the 1995 Kobe earthquake. In: Proceedings of the international conference on soil mechanics and foundation engineering-international society for soil mechanics and foundation engineering, vol 4, Aa balkema, pp 2047-2074

Ishihara K (2003) Soil behavior in earthquake Geotechnics, Oxford press

Iwasaki T (1978) A practical method for assessing soil liquefaction potential based on case studies at various sites in Japan. In: Proc. Second Int. Conf. Microzonation Safer Construction Research Application, vol 2, pp 885-896

Iwasaki T (1982) Microzonation for soil liquefaction potential using simplified methods. In: Proceedings of the 3rd international conference on microzonation, vol 3, Seattle, pp 1310-1330

Iwasaki T, Tatsuoka F, Takagi Y (1978) Shear moduli of sands under cyclic torsional shear loading. Soils Found 18(1):39-56

Jack W, Baker (2008) An Introduction to Probabilistic Seismic Hazard Analysis PSHA, Version 1.3

Jafarzadeh F, Shahrabi MM, Jahromi HF (2015) On the role of topographic amplification in seismic slope instabilities. J Rock Mech Geotech Eng 7(2): 163-170

Kaklamanos J, Baise LG, Thompson EM, Dorfmann L (2015) Comparison of 1D linear, equivalent-linear, and nonlinear site response models at six KiK-net validation sites. Soil Dyn Earthq Eng 69:207-219

Kaklamanos J, Bradley BA, Thompson EM, Baise LG (2013) Critical parameters affecting bias and variability in site-response analyses using KiK-net downhole array data. Bull Seismol Soc Am 103(3):1733-1749

Kanai K, Tanaka T (1961) On microtremors VIII. Bull Earthq Res Inst, Univ Tokyo 39 : 97-114

Kanli Al, Tildy P, Pr'onay Z, Pınar A, Hermann L (2006) Vs ${ }^{30}$ mapping and soil classification for seismic site effect evaluation in dinar region, SW Turkey. Geophys Int 165:223-235

Kassegne SK, Engeda S, Kebede A, Tessema E (2012) Notes and Proposed Guidelines on Updated Seismic Codes in Ethiopia-Implications for LargeScale Infrastructures
Kawase H (1990) The cause of the damage belt in Kobe: the basin edge effect constructive interference of the direct S-wave with the basin-induced diffracted/Rayleigh waves. Seismol Res Lett 67:25-34

Kebede F, Asfaw L (1996) Seismic hazard assessment for Ethiopia and the neighboring countries. SINET Ethiop J Sci 19(1):15-50

Kebede F, Van Eck T (1996) Probabilistic seismic hazard assessment for the horn of Africa based on seismotectonic regionalization. Tectonophysics 270(3-4): 221-238

Kebede F, Van Eck T (1997) Probabilistic seismic hazard assessment for the horn of Africa based on seismotectonic regionalization. Tectonophysics 270(3-4): $221-238$

King J, Tucker B (1984) Observed variations of earthquake motion across a sediment-filled valley. Bull Seismol Soc Am 74:137-151

Kokusho T (1980) Cyclic Triaxial test of dynamic soil properties for wide strain range. Soils Found 20:45-60

Kokusho T (1987) In-situ Dynamic Soil Properties and their Evaluations, Proc. 8th Asian Regional Conference on Soil Mechanics and Foundation Engineering, Kyoto, Japan, (2), pp 215-240

Kramer SL (1996) Geotechnical earthquake engineering. Prentice-Hall, Upper Saddle

Kramer SL, Paulsen SB (2004) Practical use of geotechnical site response models. In: International workshop on uncertainties in nonlinear soil properties and their impact on modeling dynamic soil response. PEER Center Headquarters, Richmond

Krinitzsky EL (1995) Deterministic versus probabilistic seismic hazard analysis for critical structures. Eng Geol 40(1-2):1-7

Krinitzsky EL (2003) How to combine deterministic and probabilistic methods for assessing earthquake hazards. Eng Geol 70:157-163 https://doi.org/10.1016/ S0013-7952(02)00269-7

Kuo CH, Wen KL, Hsieh HH, Lin CM, Chang TM, Kuo KW (2012) Site classification and Vs30 estimation of free-field TSMIP stations using the logging data of EGDT. Eng.Geol. 129-130(68):75 https://doi.org/10.1016/j.enggeo.2012.01.013

Lee CT, Huang CC, Lee JF, Pan KL, Lin ML, Dong JJ (2008) Statistical approach to earthquake-induced landslide susceptibility. Eng Geol 100(1-2):43-58

Liu AH, Stewart JP, Abrahamson NA, Moriwaki Y (2001) Equivalent number of uniform stress cycles for soil liquefaction analysis. J Geotech Geoenviron Eng 127(12):1017-1026

Maheshwari BK, Mahajan AK, Sharma ML, Paul DK, Kaynia AM, Lindholm C (2013) Relationship between shear velocity and SPT resistance for sandy soils in the Ganga basin. Int J Geotech Eng 7(1):63-70

Malek MM, Pezeshk S (2015) Ground motion site amplification factors for sites located within the Mississippi embayment with consideration of deep soil deposits. Earthquake Spectra 31(2):699-722

Mammo T (2005) Site-specific ground motion simulation and seismic response analysis at the proposed bridge sites within the city of Addis Ababa. Ethiopia Eng Geo 79(3-4):127-150

Manga M, Wang CY (2007) Earthquake hydrology, in treatise on geophysics, G. Schubert editor, vol 4, pp 293-320

Manga M, Wang CY (2015) Earthquake hydrology. Treatise on geophysics, vol 4, 2nd edn. Oxford Elsevier, pp 305-328

Marcuson WF, Marcuson WI, El K, Er K (1977) Earthquake Analysis of Fort Peck Dam, Montana

Matthew WJ, Michael K, Andy N, Juliet B, James W, Birhanu Y, Ayele A, Bedada T (2017) Seismicity associated with magmatism, faulting and hydrothermal circulation at Aluto volcano, Main Ethiopian rift, VOLGEO-06063. Elsevier, p 16

McGuire RK (2001) Deterministic vs. probabilistic earthquake hazards and risks. Soil Dyn 211 Earthq Eng 21:377-384 https://doi.org/10.1016/ S02677261(01)00019-7

McGuire RK (2008) Probabilistic seismic hazard analysis: early history. Earthq Eng Struct Dyn 37:329-338

Medvedev S, Sinityma A (1965) Seismic effects on earth fill dams. Proc. 3rd World Conf. Earthq. Eng., Paper IV/M/18

Meissner R (2002) The little book of planet earth. Copernicus Books, New York

Mekonen, Kebede F (2011) Suitability of Koga Watershed for Irrigated Sugarcane and Onion Production in the Blue Nile Basin, Ethiopia. J Dry Lands 4(2):325-332

Mekonnen B (1995) EBCS-8: Basis of design, proceedings of the Ethiopian Association of Seismology and Earthquake Engineering (EASEE) on seismic Hazard assessment and Design of Structures for earthquake resistance, Addis Ababa, Ethiopia, pp 25-38

Mengistu A (2003) Seismic Microzonation for central Addis Ababa. Addis Ababa University, Addis Ababa University, Ethiopia, unpublished Msc thesis 
Midorikawa S (1987) Prediction of Isoseismal Map in the Kanto Plain Due to Hypothetical Earthquake. J Struct Eng 33B:43-48

Midzi V, Hlatywayo DJ, Chapola LS, Kebede F, Atakan K, Lombe DK, Tugume FA (1999) Seismic hazard assessment in Eastern and Southern Africa. Ann Geophys 42(6)

Ministry of Construction. (2015) Design of Structures for earthquake resistance, Ethiopian standards based on euro norms (ES EN 1998:2015), Addis Ababa

Mohamed AME (2003) Estimating earthquake ground motions at the Northwestern part of the Gulf of Suez, Egypt, Ph.D. Thesis, Fac. Sc., Ain Shams Uni, pp 93-138

Moyle WR (1980) Ground-Water Level Monitoring for Earthquake Prediction, A Progress Report Based on Data Collected in Southern California 1976-79, United States Geological Survey, Open-File Report, pp 80-413

Mucciarelli M, Masi A, Gallipoli MR, Harabaglia P, Vona M, Ponzo F, Dolce M (2004) Analysis of RC building dynamic response and soil-building resonance based on data recorded during a damaging earthquake (Molise, Italy). Bull Seismol Soc Am 94(5):1943-1953

Mukherjee B, Habib MF, Dikbiyik F (2014) Network adaptability from disaster disruptions and cascading failures. IEEE Commun Mag 52(5):230-238

Muluneh AA, Kidane T, Corti G, Keir D (2018) Constraints on fault and crustal strength of the main Ethiopian rift from formal inversion of earthquake focal mechanism data. Tectonophysics 731:172-180

Naganoh M, Kagami H, Muratami H (1993) Effects of surface and subsurface irregularities. In: Earthquake motions and ground conditions, The Architectural Institute of Japan, Tokyo

Nakamura Y (1989) A method for dynamic characteristics estimation of subsurface using microtremor on the ground surface. Q Rep Railway Tech Res Inst 30(1):25-33

Nath RR, Jakka RS (2012) Effect of bedrock depth on site classification. Indian Institute of Technology, Roorkee

Naveen James T, Sitharam G, Padmanabhan G, Pillai CS (2014) Seismic microzonation of a nuclear power plant site with detailed geotechnical, geophysical and site effect studies. Nat Hazards 71:419-462

Nguyen KV, Gatmiri B (2007) Evaluation of seismic ground motion induced by topographic irregularity. Soil Dyn Earthq Eng 27:183-188

Özel O, Cranswick E, Meremonte M, Erdik M, Safak E (2002) Site Effects in Avcilar, West of Istanbul, Turkey, from Strong- and Weak-Motion Data. BSSA 92(1): 499-508

Panjamani A, Kumar Katukuri A, Moustafa SSR, NSN A-A (2018) Seismic site classification and amplification of shallow bedrock sites. PLoS One 13(12): 0208226 https://doi.org/10.1371/journal.pone.0208226

Papathanassiou G (2008) LPI-based approach for calibrating the severity of liquefaction-induced failures and for assessing the probability of liquefaction surface evidence. Eng Geol 96(1-2):94-104

Papathanassiou G, Pavlides S, Ganas A (2005) The 2003 Lefkada earthquake: field observations and preliminary microzonation map based on liquefaction potential index for the town of Lefkada. Eng Geol 82:12-31 https://doi.org/ 10.1016/j.enggeo.2005.08.006

Park CB, Miller RD, Xia J (1999) Multi-channel analysis of surface waves. Geophysics 64(3):800-808

Paudyal YR, Yatabe R, Bhandary NP, Dahal RK (2012) A study of local amplification effect of soil layers on ground motion in the Kathmandu Valley using microtremor analysis. Earthq Eng Eng Vib 11(2):257-268

Paudyal YR, Yatabe R, Bhandary NP, Dahal RK (2013) Basement topography of the Kathmandu Basin using microtremor observation. J Asian Earth Sci 62:627637

Phillips WS, Aki K (1986) Site amplification of coda waves from local earthquakes in central California. Bull Seismol Soc Am 76(3):627-648

Pitilakis K, Anastasiadis A, Raptakis D (1992) Field and Laboratory Determination of Dynamic Properties of Natural Soil Deposits, Proc. 10th World Conference on Earthquake Engineering., Madrid, (5), pp 1275-1280

Pitilakis K, Kirtas E, Sextos A, Bolton MD, Madabhushi SPG Brennan AJ (2004) Validation by centrifuge testing of numerical simulations for soil-foundationstructure systems. Proc., 13th World Conf. Earthquake Engrg., Vancouver, B.C., Canada, Paper No. 277

Prasad SK, Vijayendra KV (2017) Relevance of Site Characterization in Seismic Studies, Indian. J Adv Chem Sci 5(1):59-64 https://doi.org/10.22607/IJACS 2017.501009

Rahman MZ (2019) Probabilistic seismic Hazard analysis with nonlinear site response and liquefaction potential evaluation for deep sedimentary deposits, Phd Dissertation, University of British Columbia (Okanagan)
Reiter L (1990) Earthquake hazard analysis: issues and insights. Columbia University Press, New York

Robertson PK, Campanella RG (1985) Liquefaction potential of sands using the CPT. J Geotech Eng 111:384-403

Robertson PK, Wride CE (1998) Evaluating cyclic liquefaction potential using the cone penetration test. Can Geotech J 35:442-459 https://doi.org/10.1139/t98017

Rodriguez-Marek A, Bray JD, Abrahamson NA (2001) An empirical geotechnical seismic site response procedure. Earthquake Spectra 17(1):65-87

Rovelli (1998) Amplification of ground motion due to topography and sedimentary filling in the Nocera Umbra area (Central Italy). In: Proceedings of the International Conference on the effects of Surface Geology on Seismic motion, Yokohama, Japan, vol 2, pp 531-536

Samuel K, Samson E, Asnake K, Eyob T (2009) Technical Notes and Proposed Guidelines on Updated Seismic Codes in Ethiopia -Implications for LargeScale Infrastructures

Schnabel P, Seed HB, Lysmer J (1972b) Modification of seismograph Records for Effects of local soil conditions. Bull Seismol Soc Am 62(6):1649-1664

Schnabel P, Seed HB, Lysmer J, Erratum (1973) Modification of seismograph Records for Effects of local soil conditions. Bull Seismol Soc Am 63(2):750

Schnabel PB, Lysmer J, Seed HB (1972a) SHAKE a computer program for earthquake response analysis of horizontally layered sites, report no. EERC 72 12, University of California, Berkeley, Calif., earthquake engineering research Centre

Schnabel PB, Lysmer J, Seed HB (1972C) SHAKE - a computer 145 program for earthquake response analysis of horizontally layered sites, report no. EERC7212, University of California Berkeley

Schnabel PB, Lysmer J, Seed HB (1991) SHAKE91, A Computer Program for Earthquake Response Analysis of Horizontal Layered Sites, EERC (Earthquake Engineering Research Center), College of Engineering. University of California Berkeley, California

Seed HB, Idriss IM (1970) Analyses of ground motions at Union Bay, Seattle during earthquakes and distant nuclear blasts. Bull Seismol Soc Am 60(1): $125-136$

Seed HB, Idriss IM (1972) Simplified procedure for evaluating soil liquefaction potential. J Soil Mech Foundations Div 97(SM9):1249-1273

Seed HB, Idriss IM (1982) Ground motions and soil liquefaction during earthquakes. Earthquake Engineering Research Institute Monograph, Oakland

Seed HB, Romo MP, Sun JJ, Lysmer J (1986a) Relationships between Soil Conditions and Earthquake Ground Motions in Mexico City in the Earthquake of September 19, 1985. Report No. UCB/EERC-87/15, Earthquake Eng. Res. Center, College of Eng., University of California, Berkeley, CA

Seed HB, Schnabel P (1972) Soil and geologic effects on site response during earthquakes. In: Proc. Inter. Conf. Microzonation (Seattle,Washington), vol 1, pp 61-85

Seed HB, Tokimatsu K, Harder LF, Chung R (1984) The influence of SPT procedures on soil liquefaction resistance evaluations. Report no. UCB/EERC$84 / 15$, earthquake engineering research center, University of California, Berkeley

Seed HB, Tokimatsu K, Harder LF, Chung RM (1985) Influence of SPT procedures in soil liquefaction resistance evaluations. J Geotech Eng 111:14251445 https://doi.org/10.1061/(ASCE)079410(1985)111:12(1425)

Seed HB, Wong RT, Idriss IM, Tokimastu K (1986b) Moduli and damping factors for dynamic analysis of cohesionless soils. J Geotech Engg, ASCE 112(11): 1016-1032

Seed RB, Cetin KO, Moss PJ, Riemer M (2001) Recent advances in soil liquefaction engineering and seismic site response evaluation. In: Proceedings of 4th International Conference and Symposium on Recent Advances in Geotechnical Earthquake Engineering and Soil Dynamics. University of Missouri, Rolla, p SPL-2

Seed RB, Cetin KO, Moss RE, Kammerer AM, Wu J, Pestana JM, Faris A (2003) Recent advances in soil liquefaction engineering: a unified and consistent framework. In: Proceedings of the 26th Annual ASCE Los Angeles Geotechnical Spring Seminar: Long Beach, CA

Seed RB, Harder LF (1990) SPT-based analysis of cyclic pore pressure generation and undrained residual strength. $H$. Bolton Seed memorial symposium proceedings, vol 2. BiTech publishers Itd, Vancouver, B.C

Seged HC, Haile M (2010) Earthquake induced liquefaction analysis of Tendaho earth-fill dam. J EEA 27

Semblat J-F, Duval A-M, Dangla P (2000) Numerical analysis of seismic wave amplification in Nice (France) and comparisons with experiments. Soil Dyn Earthq Eng 19:347-362 
Simkin MV, Garnero EJ, Fouch MJ (2003) New 3D Tools Provide Insights for Earth Interior Research, Visualization, and Education. In: AGU Fall Meeting Abstracts, vol 2003, pp ED31E-ED305E

Sitharam TG, Anbazhagan P (2008) Seismic microzonation: principles, practices and experiments. EJGE Special Volume Bouquet, 08, http://www.ejge.com/ Bouquet08/Sitharam/Sitharam_ppr.pdf

Skempton AW (1986) Standard penetration test procedures and the effects in sands of overburden pressure, relative density, particle size, ageing and overconsolidation. Geotechnique 36(3):425-447

Slob S, Hack R, Scarpas T, van Bemmelen B, Duque A (2002) A methodology for seismic microzonation using GIS and SHAKE - a case study from Armenia, Colombia. In: Engineering geology for developing countries-proceedings of 9th congress of the international association for engineering geology and the environment, Durban, South Africa

Soebowo E (2016) Identification of Liquefaction Hazard in the Coastal Area of Merak-Anyer, Banten based on CPT and SPT Data. JurnalSegara 12(2)

Sonmez B, Ulusay R, Sonmez H (2008) A study on the identification of liquefactioninduced failures on ground surface based on the data from the 1999 Kocaeli and Chi-Chi earthquakes. Eng Geol 97(3-4):112-125

Sonmez H (2003) Modification of the liquefaction potential index and liquefaction susceptibility mapping for a liquefaction-prone area (Inegol, Turkey). Environ Geol 44(7):862-871

Spudich P, Fletcher JB, Hellweg M, Boatwright J, Sullivan C, Lindh Joyner WBAG (1997) SEA96-A new predictive relation for earthquake ground motions in extensional tectonic regimes. Seismol Res Lett 68(1):190-198

Spudich P, Hellweg M, Lee WHK (1996) Directional topographic site response at Tarzana observed in aftershocks of the 1994 Northridge, California, earthquake: implications for mainshock motions. Bull Seismol Soc Am 86(1B): S193-S208

Stark EW (1995) U.S. Patent No. 5,379,238. U.S. Patent and Trademark Office, Washington, DC

Stark TD, Olson SM (1995) Liquefaction resistance using CPT and field case histories. J Geotech Eng ASCE 121(12):856-869

Stewart JP, Andrew HL, Yoojoong C (2003) Amplification factors for spectral acceleration in tectonically active regions. Bull Seismol Soc Am 93(1):332-352

Stone WC, Yokel FY, Celebi M, Hanks T, Leyendecker EV (1987) Engineering aspects of the September 19, 1985 Mexico earthquake, NBS building science series 165. National Bureau of Standards, Washington, D. C

Sugito M, Goda H, Masuda T (1994) Frequency dependent equi-linearized technique for seismic response analysis of multi-layered ground. Doboku GakkaiRombun-Hokokushu 493(3-2):49-58

Sun JI, Golesorkhi R, Seed HB (1988) Dynamic moduli and damping ratios for cohesive soils., EERC report no.UCB/EERC-88/15

TC4- ISSMGE (1999) Manual for Zonation on Seismic Geotechnical Hazard, Revised edition. Technical Committee for Earthquake Geotechnical Engineering (TC4) of the International Society of Soil Mechanics and Geotechnical Engineering (ISSMGE) 209

Tertulliani A (2000) Qualitative effects of local geology on damage pattern. Bull Seismol Soc Am 90(6):1543-1548

Topal T, Doyuran V, Karahanoglu N, Toprak V, Yesilnacar Suzen MLE (2003) Microzonation for earthquake hazards: Yenisehir settlement, Bursa, Turkey. Eng Geol 70(1):93-108

US Department of Transportation. (1997) Geotechnical Earthquake engineering for highways, Volume I, Design Principles, Washington DC

Varnes DJ (1984) Landslide hazard zonation: a review of principles and practice, Natural Hazards

Vittoz P, Stewart GH, Duncan RP (2001) Earthquake impacts in old growth Nothofagus forests in New Zealand. J Veg Sci 12(3):417-426

Vungania M, Dumisani J, Hlatywayo LS, Chapola KF, Kuvvet A, Lombe DK, Turyomurugyendo G, Tugume FA (1999) Seismic hazard assessment in eastern and southern Africa. Ann Geofis 42(6)

Wakamatsu K (1992) Evaluation of liquefaction susceptibility based on detailed geomorphological classification. In: Proceedings of technical papers of annual meeting architectural institute of Japan, B, pp 1443-1444

Wald DJ, Allen TI (2007) Topographic slope as a proxy for seismic site conditions and amplification. Bull Seismol Soc Am 97:1379-1395

Wazoh HN, Mallo SJ (2014) Standard Penetration Test in Engineering Geological Site Investigations - A Review. Int J Eng Sci (IJES) 3 I(7):40-48

Wilks M, Ayele A, Kendall JM, Wookey J (2017) The 24th January 2016 Hawassa earthquake: Implications for seismic hazard in the Main Ethiopian rift. J Afr Earth Sci 125:118-125
Wills CJ, Clahan KB (2006) Developing a map of geologically defined sitecondition categories for California. Bull Seismol Soc Am 96(4A):1483-1501

Worku A (2013) Technical notes; Seismic soil-structure interaction as a potential tool for economical seismic design of building structures. J EEA 30:243-295

Yoshida N, Kobayashi S, Suetomi I, Miura K (2002) Equivalent linear method considering frequency dependent characteristics of stiffness and damping. Soil Dyn Earthq Eng 22(3):205-222

Youd TL (1984) Geologic effects - Liquefaction and associated ground failure, Proceedings of the Geologic and Hydrologic hazards training program. Open-FileReport 84, 760 (U.S. Geological Survey), pp 210-232

Youd TL (1991) Mapping of earthquake-induced liquefaction for seismic zonation proceedings, 4th international conference on seismic zonation, earthquake

Youd TL, Idriss IM (2001) Liquefaction resistance of soils: summary report from the 1996 NCEER and 1998 NCEER/NSF workshops on evaluation of liquefaction resistance of soils. J Geotech Geoenviron 127(4):297-313

Youd TL, Idriss IM, Andrus RD, Arango I, Castro G, Christian JT, Dobry R, Finn WDL, Harder LF, Hynes ME, Ishihara K, Koester JP, Liao SSC, Marcuson WF, Martin GR, Mitchell JK, Moriwaki Y, Power MS, Robertson PK, Seed RB, Stokoe KH (2001) Liquefaction resistance of soils: summary report from the 1996 NCEER 14 and 1998 NCEER/NSF workshop on evaluation of liquefaction resistance of soils. J Geotech Geoenviron 127(10):817-833

Youd TL, Noble SK (1997) Liquefaction criteria based on statistical and probabilistic analyses. In: Proc., NCEER Workshop on Evaluation of Liquefaction Resistance of Soils, NCEER Technical Rep. No: NCEER-97, vol 22 , pp 201-205

\section{Publisher's Note}

Springer Nature remains neutral with regard to jurisdictional claims in published maps and institutional affiliations.

\section{Submit your manuscript to a SpringerOpen ${ }^{\circ}$ journal and benefit from:}

- Convenient online submission

- Rigorous peer review

- Open access: articles freely available online

High visibility within the field

- Retaining the copyright to your article

Submit your next manuscript at $>$ springeropen.com 